\title{
Facilitation of Calcium-Dependent Potassium Current
}

\author{
Stuart H. Thompson \\ Department of Biological Sciences, and the Hopkins Marine Station, Stanford University, Pacific Grove, California 93950
}

The activation of Ca-dependent $K^{+}$current, $I_{c}$, was studied in macropatches on the cell bodies of molluscan neurons. When a depolarizing voltage-clamp pulse was applied repeatedly, $I_{c}$ facilitated in a manner that resembled the facilitation of synaptic transmitter release. Facilitation was characterized by an increase in $I_{c}$ amplitude, a progressive increase in instantaneous outward current, and a decrease in utilization time. Experiments were done to investigate the mechanism responsible for $I_{c}$ facilitation. Facilitation was reduced by microinjection of an exogenous $\mathrm{Ca}^{2+}$ buffer into the cytoplasm, indicating that facilitation is a $\mathrm{Ca}^{2+}$-dependent process. It was also reduced at elevated temperatures. Conversely, facilitation was greatly potentiated by blocking the $\mathrm{Na} / \mathrm{Ca}$ exchange mechanism. It is concluded that the facilitation of $\mathrm{Ca}$-dependent $\mathrm{K}^{+}$current results from the accumulation of $\mathrm{Ca}^{2+}$ at the inner face of the membrane during the repeated activation of $\mathrm{Ca}^{2+}$ channels by depolarization. The $\mathrm{Ca}^{2+}$ indicator fluo-3 was used in fluorescence imaging experiments to measure changes in [Ca], near the cell membrane during repeated depolarizing pulses and the interpretation of these results was aided by numerical simulations of $\mathrm{Ca}^{2+}$ accumulation, diffusion, and buffering in the peripheral cytoplasm. These experiments showed that the time course of $I_{c}$ facilitation matches the time course of $\mathrm{Ca}^{2+}$ accumulation at the membrane. It was found that the strength of $I_{c}$ facilitation varies among patches on the same neuron, suggesting that the accumulation of $\mathrm{Ca}^{2+}$ is not uniform along the inner surface of the membrane and that gradients in [Ca], develop and are maintained during trains of depolarizing pulses. Potential mechanisms that may lead to local differences in $\mathrm{Ca}^{2+}$ accumulation and $I_{\mathrm{c}}$ facilitation are discussed.

IKey words: facilitation, Ca-dependent $\mathrm{K}^{+}$current, $\mathrm{Ca}^{2+}$ accumulation, macropatch clamp, fluo-3 imaging, $\mathrm{Ca}^{2+}$ diffusion model]

Calcium ions entering at voltage-dependent $\mathrm{Ca}^{2+}$ channels accumulate in the cytoplasm near the cell membrane where the change in local $\mathrm{Ca}^{2+}$ concentration influences important cellular events, including ion channel gating and exocytosis. Voltageclamp and calcium imaging methods were used to study the dynamics of $[\mathrm{Ca}]_{i}$ in the proximity of the cell membrane during repeated voltage-clamp steps in neurons isolated from the nudibranch mollusk Doriopsilla. These neurons express Ca-de-

\footnotetext{
Received Apr. 8, 1994; revised June 13, 1994; accepted June 16, 1994.

1 thank the staff of the Hopkins Marine Station for support, Ms. S. Alin for technical assistance, and Dr. S. S.-H. Wang and Mr. C. Mathes for helpful discussions. Research was supported by BNS 9021217.

Correspondence should be addressed to Stuart H. Thompson, Hopkins Marine Station, Ocean View Boulevard, Pacific Grove, CA 93950.

Copyright (C) 1994 Society for Neuroscience 0270-6474/94/147713-13\$05.00/0
}

pendent potassium current, termed $I_{\mathrm{C}}$ (Thompson, 1977), and the activation of this current provides a linear index of $[\mathrm{Ca}]_{i}$ adjacent to the inner face of the membrane (Lando and Zucker, 1989). Ionic currents were recorded from macropatches enriched in $I_{\mathrm{C}}$ channels, and it was found that the amplitude of $I_{\mathrm{C}}$ increases during repeated depolarizations. Ca-dependent $\mathrm{K}$ currents play important roles in the regulation of neuronal excitability and are responsible for spike frequency adaptation during repetitive firing, for poststimulus hyperpolarization and for pacemaker activity (Smith and Thompson, 1987). The facilitation of $I_{C}$ affects these integrative functions.

It is concluded that $\mathrm{Ca}^{2+}$ accumulation near the membrane is responsible for the increase in outward current during repeated voltage-clamp pulses. Facilitation varies in strength between different locations on the same neuron, suggesting that $\mathrm{Ca}^{2+}$ accumulation near the membrane is not spatially homogeneous and that gradients in [Ca $]_{i}$ develop and are maintained during pulse trains. Two factors that contribute to the spatial variability of outward current facilitation were identified: the nonuniform clustered distribution of $\mathrm{Ca}^{2+}$ channels, and active $\mathrm{Ca}^{2+}$ transport mechanisms at the membrane.

\section{Materials and Methods}

Voltage-clamp methods. Neuron cell bodies were acutely dissociated from the pleural ganglia of the nudibranch mollusk Doriopsilla albopunctata using the procedure described by Thompson and Coombs (1988) and voltage clamped with a two-microelectrode method. A separate voltage clamp was used to hold the bath at ground potential, and the output of this amplifier provided a measure of the whole-cell current. Membrane currents were measured simultaneously from macropatches using the loose-patch technique described by Johnson and Thompson (1989). Voltage-clamp records were digitized and analyzed using pcLAMP software (Axon Inst.).

The normal external saline contained (mм) $450 \mathrm{NaCl}, 10 \mathrm{KCl}, 10$

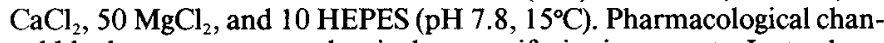
nel blockers were not used to isolate specific ionic currents. Instead, we took advantage of the fact that ion channels occur in clusters on the cell bodies of these neurons (Thompson and Coombs, 1988; Premack et al., 1989; Wang and Thompson, 1992). The patch pipette was moved to sample currents from a number of macropatches on the same cell until a location was found where repeated depolarizing pulses elicited facilitating outward currents. Such patches are enriched in Ca-dependent $\mathrm{K}^{+}$channels, sometimes to the exclusion of other channel types. This strategy was adopted to study outward current facilitation in cells bathed in normal physiological saline and without intracellular dialysis, a condition in which $\mathrm{Ca}^{2+}$ regulatory mechanisms are minimally disturbed.

$\mathrm{Ca}^{2+}$ imaging methods. Neurons were loaded with fluo-3 by iontophoresis from a micropipette containing $1 \mathrm{~mm}$ dye dissolved in 100 mM HEPES buffer ( $\mathrm{pH} 7.8$ ) and imaged on an upright epifluorescence microscope using high-NA $10 \times$ and $20 \times$ objectives. Isolated neurons were cleared of adherent connective tissue and adjacent cells and placed on a Sylgard pedestal so that the edge of the cell body of a single neuron could be clearly seen in transmitted light. Fluorescence images were acquired with an SIT camera (Cohu) using mercury arc illumination, a $490 \mathrm{~nm}$ excitation interference filter, and a $530 \mathrm{~nm}$ emission filter (10 $\mathrm{nm}$ bandwidth; Omega). Video images were stored on VHS tape or 


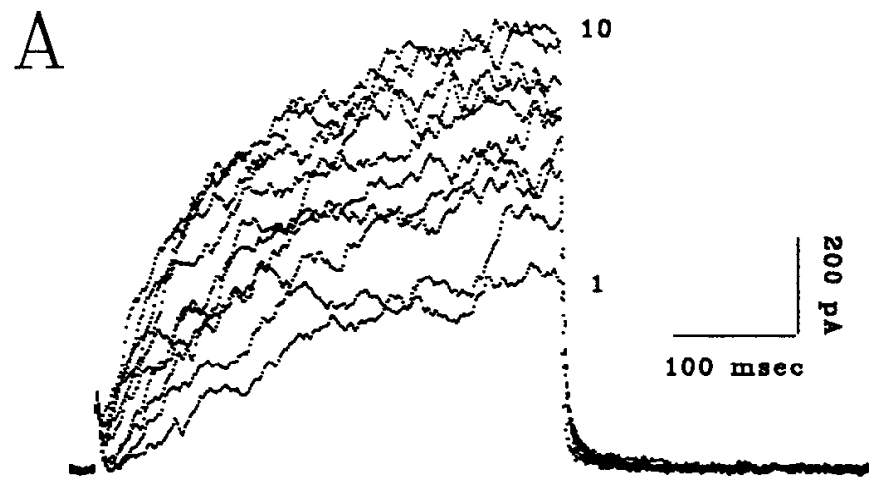

$\mathrm{B}$
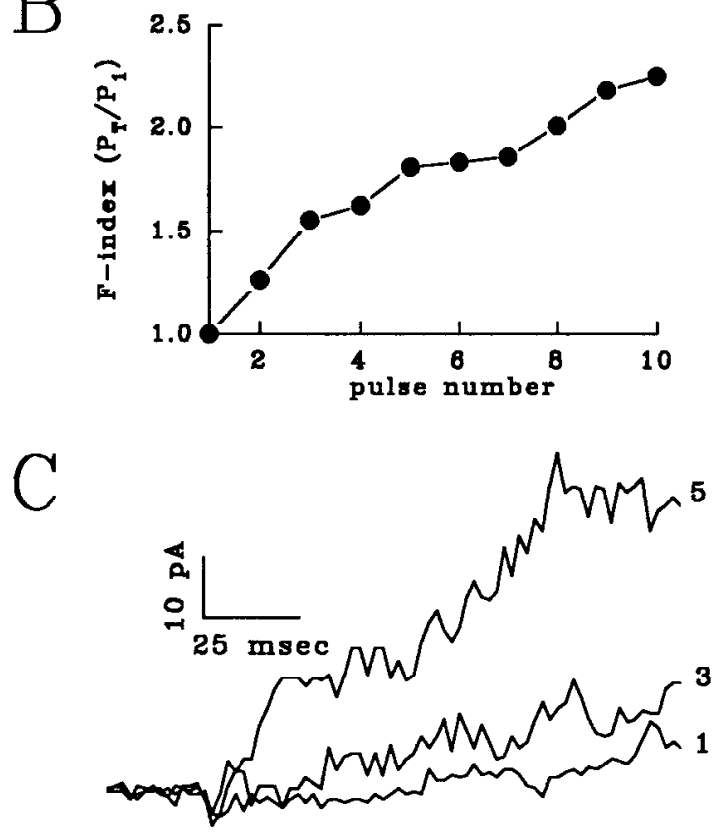

Figure 1. Outward current facilitation during repeated pulses. $A$, Macropatch currents recorded during a series of ten $300 \mathrm{msec}$ voltage-clamp pulses from a holding voltage of -40 to a test voltage of +15 . The pulses were repeated at a rate of $1 / \mathrm{sec}$, and the currents resulting from pulse 1 and pulse 10 are indicated. The patch pipette was positioned at the cap of the cell body, antipodal to the emergence of the axon $\left(15^{\circ} \mathrm{C}\right.$, normal saline, $1 \mathrm{kHz}$ filter). $B$, Values of $F$-index are plotted as a function of pulse number for the series shown in $A$. $F$-index was calculated by dividing the amplitude of the outward current at the end of each successive pulse in the train $\left(P_{t}\right)$ by the amplitude at the end of the first pulse $\left(P_{1}\right) . C$. Decrease in utilization time during successive pulses. The figure shows macropatch currents recorded from a different neuron during the first, third, and fifth pulses of a repetitive pulse series (holding voltage, $-40 \mathrm{mV}$; test voltage, $+10 \mathrm{mV}$; pulse rate, $1 \mathrm{~Hz}$; patch located at the soma cap; $15^{\circ} \mathrm{C}$, normal saline, $1 \mathrm{kHz}$ filter).

optical disk and a digital image processor (MegaVision) was used to calculate changes in $[\mathrm{Ca}]_{i}$ in defined regions of interest. Results are reported either as the normalized change in fluorescence intensity $(\Delta F /$ $F$ ) or in units of $\mathrm{Ca}^{2+}$ concentration calculated from the HendersonHasselbalch equation assuming $K_{D}=5 \times 10^{-7} \mathrm{M}$ and fluorescence yield $=50$ (Kao et al., 1989). Calibration required a measure of the maximum fluorescence intensity, $F_{\max }$, when the dye is saturated with $\mathrm{Ca}^{2+}$. This was done by intentionally increasing the gain of the microelectrode voltage clamp beyond stability in order to destroy the membrane as in electroporation.

Numerical simulations of $[C a]_{i}$ and $\mathbf{I}_{C}$. The shell model described by Barish and Thompson (1983) was used to simulate changes in [Ca] during repetitive pulses. The model considers the influx of $\mathrm{Ca}^{2+}$ across the cell membrane, the diffusion and binding of $\mathrm{Ca}^{2+}$ in cytoplasm, and the removal of $\mathrm{Ca}^{2+}$ from the cell by active transport. The methods are similar to those described by Smith and Zucker (1980), Lando and Zucker (1989), Sala and Hernandez-Cruz (1990), Blumenfeld et al. (1992), and Nowycky and Pinter (1993).

The $\mathrm{Ca}^{2+}$ current was patterned after the voltage-clamp measurements of Thompson and Coombs (1988). Solutions were only needed for the case where depolarizing pulses of constant amplitude are applied repeatedly from a single holding voltage. It was assumed that $\mathrm{Ca}^{2+}$ currents activate and deactivate exponentially. The time constant of activation at the test voltage, $+15 \mathrm{mV}$, was assigned a value of $7 \mathrm{msec}$ and the time constant of deactivation at the holding voltage, $-40 \mathrm{mV}$, was assigned a value of $2 \mathrm{msec}$. Thompson and Coombs (1988) showed that $\mathrm{Ca}^{2+}$ currents do not inactivate or inactivate only weakly in macropatches located at the soma cap, antipodal to the site of emergence of the axon. Because the macropatch recordings in the present study were made at the soma cap, a noninactivating $\mathrm{Ca}^{2+}$ current was assumed. The $\mathrm{Ca}^{2+}$ current reversal potential was $+140 \mathrm{mV}$. The molar influx of $\mathrm{Ca}^{2+}$ is equal to $-I_{\mathrm{Ca}} / 2 F$, where $F$ is Faraday's constant. The model assumes a single class of $\mathrm{Ca}^{2+}$ buffer sites with a dissociation constant equal to $1.0 \mu \mathrm{M}$ (Baker and Schlaepfer, 1978; Ahmed and Connor, 1988; Neher and Augustine, 1992). It was assumed that the $\mathrm{Ca}^{2+}$ buffer is homogeneously distributed in the cell volume and the buffer concentration was assigned a value of $30 \mu \mathrm{M}$, which is the concentration of high-affinity buffer in squid axoplasm measured by Baker and Schlaepher (1978). The concentration was varied between 3 and $300 \mu \mathrm{M}$ in some simulations. Calcium binding and unbinding at these sites is expected to be much more rapid than the rates of intracellular $\mathrm{Ca}^{2+}$ accumulation and recovery observed in experiments, and therefore it was assumed that the binding reaction equilibrates instantaneously. It was also assumed that the diffusion constant for $\mathrm{Ca}^{2+}$ equals $6.4 \times 10^{-6}$ $\mathrm{cm}^{2} / \mathrm{sec}$ (Hodgkin and Keynes, 1957; Albritton et al., 1992) but that bound $\mathrm{Ca}^{2+}$ is immobilized. The diffusion of $\mathrm{Ca}^{2+}$ in cytoplasm was approximated using numerical methods, assuming spherical geometry and a cell body radius of $150 \mu \mathrm{m}$. The volume of the cell body was divide 1 into concentric shells with thicknesses, beginning at the membrane, of $1,1,1,7,10,30$, and $100 \mu \mathrm{m}$. A first-order transfer of ions between adjacent shells approximates the diffusion process. It was assumed that the steady-state value of $[\mathrm{Ca}]_{i}$ is maintained by active transport and that the rate of $\mathrm{Ca}^{2+}$ efflux is proportional to $[\mathrm{Ca}]_{i}$ in the outermost shell (DiPolo and Beauge, 1983). Calcium efflux was calculated from: $J_{c}=k_{e} \mathrm{Ca}_{i}(r=0, t)$, where $k_{e}$ is a rate constant with units of $\mathrm{cm} / \mathrm{sec}$ and $\mathrm{Ca}_{i}(r=0, t)$ is the free calcium concentration in the outermost shell at time $t$. The rate constant was normally assigned a value of $3.0 \times 10^{-3} \mathrm{~cm} / \mathrm{sec}$ (Barish and Thompson, 1983) but this parameter was varied in some simulations.

A two-state model was used to describe $I_{\mathrm{C}}$ gating (Lando and Zucker, 1989; Gola et al., 1990). It assumes a single class of Ca-dependent $\mathrm{K}^{+}$ channels whose activation is directly proportional to $[\mathrm{Ca}]_{i}$ in the outermost shell (Gorman and Thomas, 1980; Hermann and Hartung, 1982; Barish and Thompson, 1983; I ando and Zucker, 1989). Because the experiments employed repeated pulses of the same amplitude, it was sufficient to assign fixed values to the voltage-dependent activation variable associated with $I_{C}$ channel gating. This variable was given a value of 0.1 times the maximum conductance at $-40 \mathrm{mV}$ and 0.8 times the maximal conductance at $+15 \mathrm{mV}$. The reversal potential for $I_{\mathrm{C}}$ was $-75 \mathrm{mV}$. Because $[\mathrm{Ca}]_{i}$ changes slowly during and after voltage clamp steps it is unlikely that the voltage-dependent gating of $I_{C}$ channels is rate limiting (Lando and Zucker, 1989), and for simplicity it was assumed that voltage-dependent gating equilibrates instantaneously. 'This assumption is supported by the experimental results presented below.

\section{Results}

\section{Outward current facilitation during repeated pulses}

Neuron cell bodies were voltage clamped with a two-microelectrode method, and whole-cell currents were recorded during repetitive voltage-clamp pulses. A cell-attached, loose-patch method was applied simultaneously to measure currents from somatic macropatches each representing $<0.1 \%$ of the cell body area. The patch electrode was moved and currents were sampled from a number of locations to isolate patches in which the outward current increased in amplitude during the pulse series. Figure $1 A$ shows currents recorded from a macropatch selected 


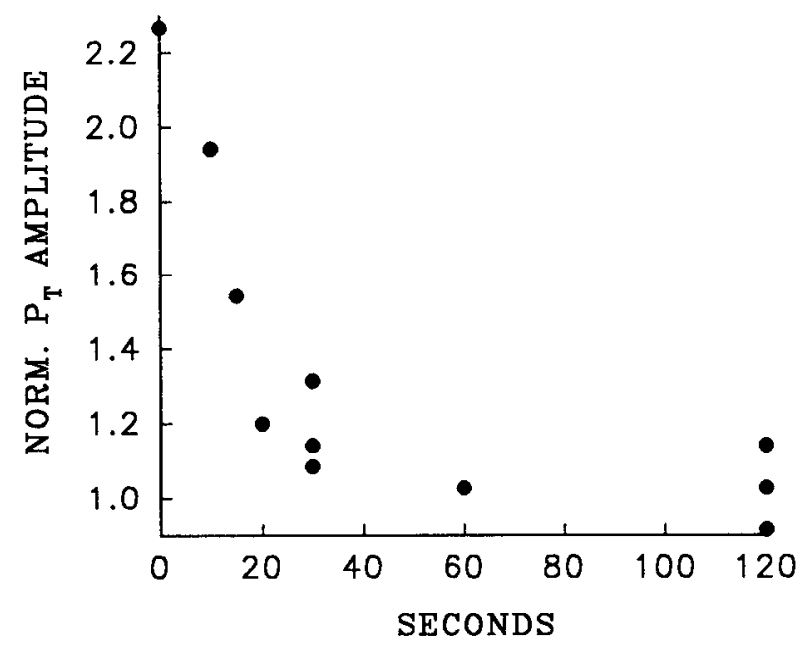

Figure 2. Time course of recovery from outward current facilitation. A conditioning train of ten $300 \mathrm{msec}$ pulses to $+15 \mathrm{mV}$ was applied at a pulse rate of $1 / \mathrm{sec}$ from a holding voltage of $-40 \mathrm{mV}$. A $300 \mathrm{msec}$ test pulse to $+15 \mathrm{mV}$ was applied at various times after the end of the conditioning train to test for residual facilitation. This procedure was repeated at $4 \mathrm{~min}$ intervals while the time between the conditioning train and the test pulse was randomly varied. Membrane current was recorded from a macropatch located near the soma cap. The maximum amplitude of the outward current during each test pulse was normalized to the mean amplitude of the unfacilitated response. The procedure was repeated three times with a test interval of $30 \mathrm{sec}$ and three times with an interval of $120 \mathrm{sec}$. The point at time $=0$ represents the value of $F$-index at the end of the conditioning train $\left(15^{\circ} \mathrm{C}\right.$, normal saline).

in this way. Ten $300 \mathrm{msec}$ pulses were applied at a rate of $1 \mathrm{~Hz}$ from a holding voltage of $-40 \mathrm{mV}$ to a test voltage of $+15 \mathrm{mV}$. This test voltage is sufficient to activate $\mathrm{Ca}^{2+}$ current to $75 \%$ of its maximum value but there is no indication of inward current in this patch.

The most striking feature of Figure $1 A$ is the progressive increase in outward current amplitude during the pulse train. The increase can be described by an $F$-index, calculated by dividing the amplitude of the outward current at the end of the last pulse in the series by its amplitude at the end of the first pulse. Identical values of $F$-index are obtained from the initial amplitudes of potassium tail currents. In this example, $F$-index approaches a saturating value of 2.3 during the series of 10 pulses (Fig. $1 B$ ). The range of values seen with this pulse sequence was $1.1-36.0$ (average $=5.5 \pm 7.6 \mathrm{SD} ; n=31$ patches on 11 cells). There is also a progressive increase in the instantaneous outward current at the beginning of each pulse and a progressive decrease in utilization time, defined as the delay between the onset of depolarization and the first appearance of outward current. The decrease in utilization time is very pronounced when there are $\mathrm{fcw} \mathrm{K}^{+}$channels in the patch (Fig. 1C). The term facilitation is used to refer to all three of these effects.

The time course of recovery from facilitation was measured by first applying a conditioning train of 10 pulses to $+15 \mathrm{mV}$ from a holding voltage of $-40 \mathrm{mV}$. A $300 \mathrm{msec}$ test pulse to $+15 \mathrm{mV}$ was applied at various times after the conditioning train to test for residual facilitation and the procedure was repealed at 4 min intervals. The maximum amplitude of the outward current during each test pulse was normalized to the amplitude measured during a single control pulse presented after an interval of 2 min, a time sufficient for complete recovery from facilitation. Figure 2 shows that recovery occurs with a

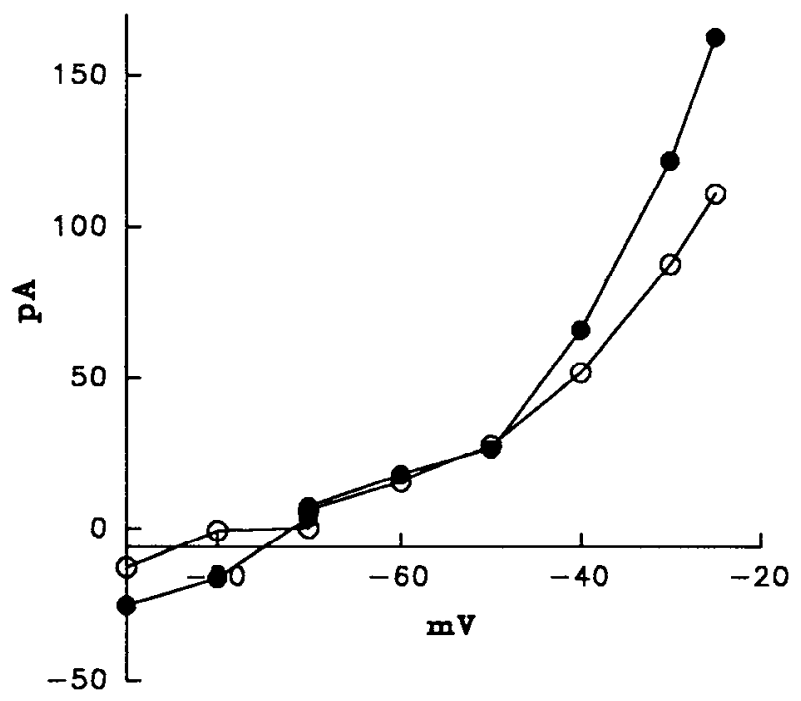

Figure 3. Instantaneous $I(V)$ curves measured from macropatch tail currents as facilitation developed. A pair of $300 \mathrm{msec}$ voltage-clamp pulses was applied from a holding voltage of $-40 \mathrm{mV}$ to a test voltage of $+15 \mathrm{mV}$. The interval between pulses was $1 \mathrm{sec}$ and the pulse pair was repeated at $2 \mathrm{~min}$ intervals. Tail currents were recorded $10 \mathrm{msec}$ after repolarizing to a series of test voltages (test pulse duration, 100 $\mathrm{msec}$ ) after pulse 1 (open symbols) and pulse 2 (solid symbols). Tail current amplitudes are plotted as a function of the repolarization voltage $\left(15^{\circ} \mathrm{C}\right.$, normal saline; macropatch located at the soma cap).

half-decay time of about $10 \mathrm{sec}$ [average at $15^{\circ} \mathrm{C}=11 \pm 2.9$ $\sec ( \pm \mathrm{SD}), n=3]$.

Instantaneous $I(V)$ curves were measured during the development of outward current facilitation. Pairs of $300 \mathrm{msec}$ pulses to $+15 \mathrm{mV}$ were applied at a pulse interval of $1 \mathrm{sec}$ and this sequence was repeated at $2 \mathrm{~min}$ intervals. Figure 3 shows $I(V)$ curves constructed from the amplitudes of macropatch tail currents measured $10 \mathrm{msec}$ after repolarizing to a series of different test voltages following both pulses in the pair. Facilitation occurs during the two-pulse sequence and the $I(V)$ curves measured after pulse 1 and pulse 2 both cross the zero current axis near $-80 \mathrm{mV}$, a voltage that approximates the $\mathrm{K}^{+}$current reversal potential (Thompson, 1977). There was no inward current in this patch, and therefore it is concluded that the change in the instantaneous $I(V)$ curve during repeated pulses results from a use-dependent increase in potassium current.

The voltage dependence of outward current facilitation was measured in two ways. In the first type of experiment, a pair of pulses to the same test voltage was applied $(300 \mathrm{msec}$ pulses; pulse interval $=1 \mathrm{sec}$ ) and macropatch tail currents were measured after returning to $-40 \mathrm{mV}$. Values of $F$-index were calculated by dividing the tail current amplitude immediately after pulse 2 by the amplitude after pulse 1 as the test voltage was varied (Fig. $4 A$ ). The second measurement used a prepulse protocol. A $300 \mathrm{msec}$ voltage-clamp pulse of variable amplitude was applied $1 \mathrm{sec}$ before a $300 \mathrm{msec}$ test pulse to $+15 \mathrm{mV}$. The amplitude of the macropatch outward current at the end of the test pulse is plotted against prepulse voltage in Figure $4 B$. The results from both protocols show that the voltage dependence of outward current facilitation follows a bell-shaped curve, increasing in value with pulses to between +20 and $+50 \mathrm{mV}$ and then decreasing with larger depolarizations. The voltage dependence of $F$-index has approximately the same shape as the $I(V)$ 


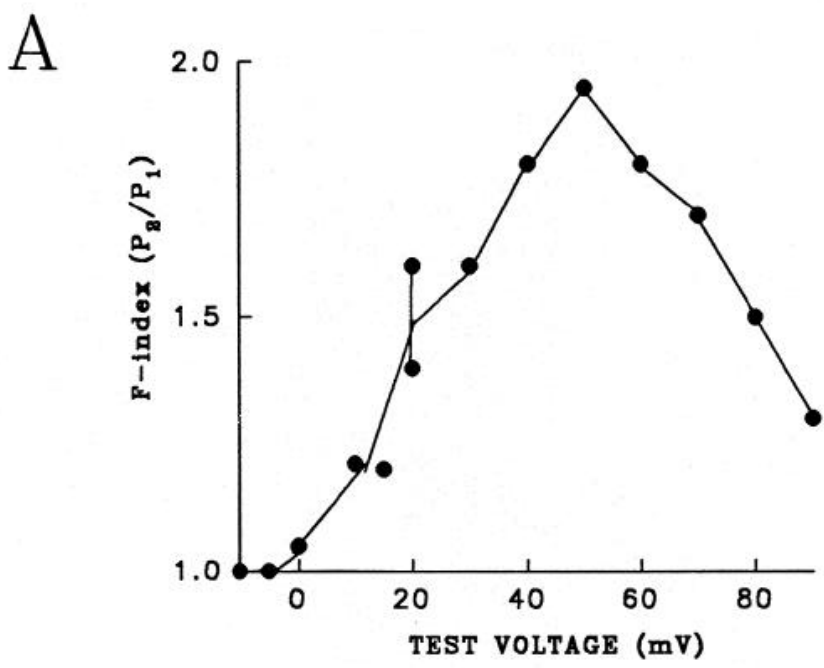

B

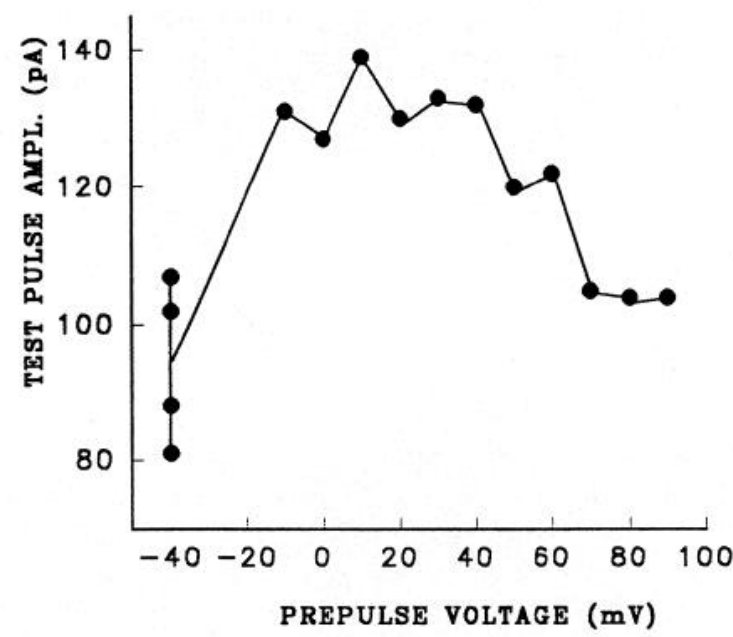

Figure 4. Voltage dependence of outward current facilitation. A, Pairs of depolarizing voltage clamp pulses (duration $=300 \mathrm{msec}$; pulse interval $=1 \mathrm{sec}$ ) were applied from a holding voltage of $-40 \mathrm{mV}$ to a series of test voltages. The pulse pair was repeated at $2 \mathrm{~min}$ intervals while the test voltage was varied. Tail currents were recorded from a macropatch located near the soma cap. The amplitude of the tail current $10 \mathrm{msec}$ after repolarizing to $-40 \mathrm{mV}$ was determined for both pulses. Values of $F$-index were calculated by dividing the tail current amplitude after pulse 2 by the amplitude after pulse 1 and are plotted as a function of test pulse voltage. Pulses to $+20 \mathrm{mV}$ were presented twice, once early in the experiment and again at the end. The difference between these two points reflects the measurement variability $\left(15^{\circ} \mathrm{C}\right.$, normal saline). $B$, Prepulse method for measuring the voltage dependence of outward current facilitation applied to a different neuron. A $300 \mathrm{msec}$ conditioning voltage-clamp pulse was applied $1 \mathrm{sec}$ before a $300 \mathrm{msec}$ test pulse to $+15 \mathrm{mV}$ (holding voltage $=-40 \mathrm{mV}$ ). The paired pulse series was repeated at $2 \mathrm{~min}$ intervals while the conditioning voltage was varied. Currents were recorded from a macropatch located near the equator of the cell body. The maximum amplitude of the outward current at the end of each test pulse is plotted against conditioning pulse voltage. The uncertainty in the measurement can be judged from the range of values obtained when the conditioning voltage equaled the holding potential, $-40 \mathrm{mV}\left(15^{\circ} \mathrm{C}\right.$, normal saline $)$.

curve for $\mathrm{Ca}^{2+}$ current (Fig. 5C), which is the expected result for a process that depends on $\mathrm{Ca}^{2+}$ influx for its activation.

The change in the instantaneous $I(V)$ curve during repeated pulses and the voltage dependence of $F$-index indicate that fa-
A
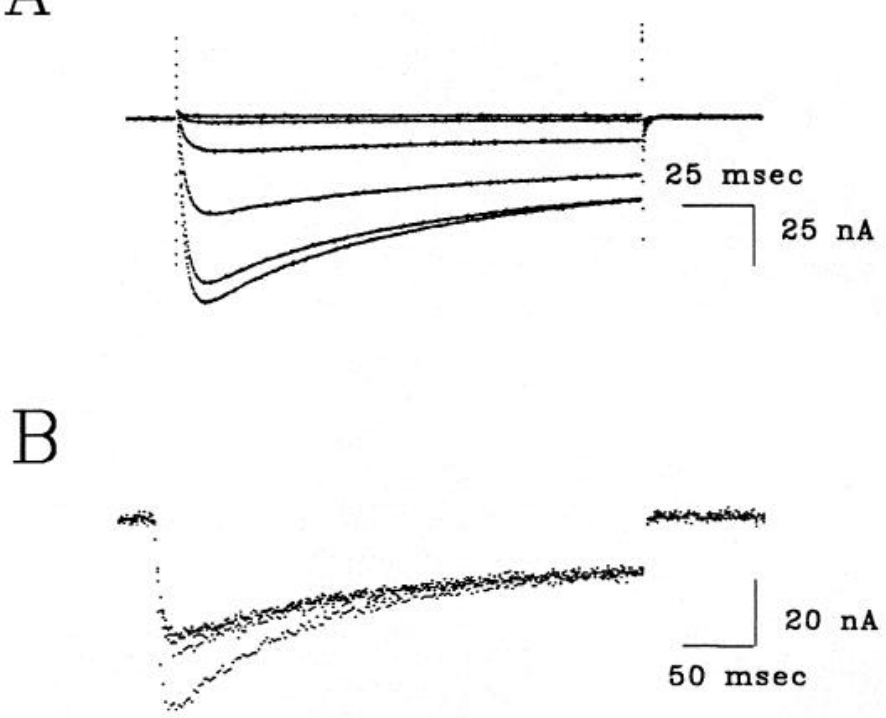

C

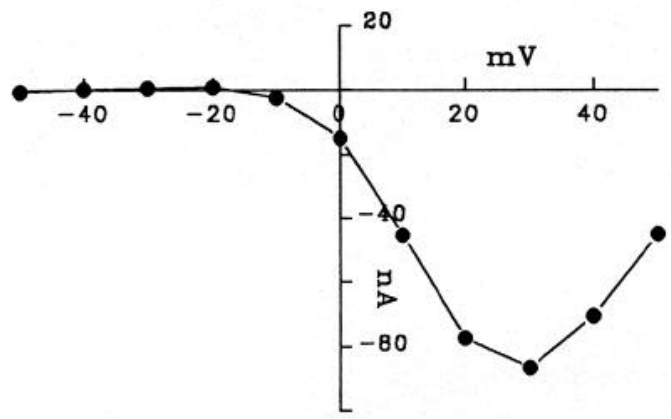

Figure 5. $\mathrm{Ca}^{2+}$ currents inactivate with use and do not facilitate. A, Whole-cell $\mathrm{Ca}^{2+}$ currents during a series of depolarizing pulses (holding voltage $=-40 \mathrm{mV}$; steps from -20 to $+30 \mathrm{mV}$ in $10 \mathrm{mV}$ increments). $B$, Inactivation of whole-cell $\mathrm{Ca}^{2+}$ current in a different neuron during a series of five pulses to $+15 \mathrm{mV}$ from a holding voltage of $-40 \mathrm{mV}$ repeated at $1 \mathrm{~Hz}$. $C$, Current-voltage relationship for $\mathrm{Ca}^{2+}$ current obtained by plotting the peak inward current amplitude as a function of test voltage. Same cell as in $A$. In all of these experiments the external saline contained (mM) $60 \mathrm{CaCl}_{2}, 300$ TEA, 180 Tris, and $104-\mathrm{AP}(\mathrm{pH}$, $7.8,15^{\circ} \mathrm{C}$ ) and the microelectrodes used for whole-cell voltage clamp were filled with $5 \mathrm{M} \mathrm{CsCl}$.

cilitation is due to an increase in potassium current and that the increase requires $\mathrm{Ca}^{2+}$ influx through voltage-dependent $\mathrm{Ca}^{2+}$ channels for its expression. The conclusion drawn from these experiments is that $\mathrm{Ca}$-dependent $\mathrm{K}^{+}$current, $I_{\mathrm{C}}$, is the ionic current species that facilitates, a conclusion that is consistent with the single-channel studies of Gola et al. (1990).

\section{$\mathrm{Ca}^{2+}$ currents inactivate and do not facilitate during repeated pulses}

Figure $5 A$ shows whole cell $\mathrm{Ca}^{2+}$ currents in response to a series of voltage-clamp steps to potentials between -20 and $+30 \mathrm{mV}$ from a holding voltage of $-40 \mathrm{mV}$. The $\mathrm{Ca}^{2+}$ current partially inactivates during depolarizing pulses and inactivation becomes more pronounced as the test voltage is increased within this range. Figure $5 B$ shows whole-cell $\mathrm{Ca}^{2+}$ currents recorded in a different neuron during five $340 \mathrm{msec}$ pulses to $+15 \mathrm{mV}$ applied 


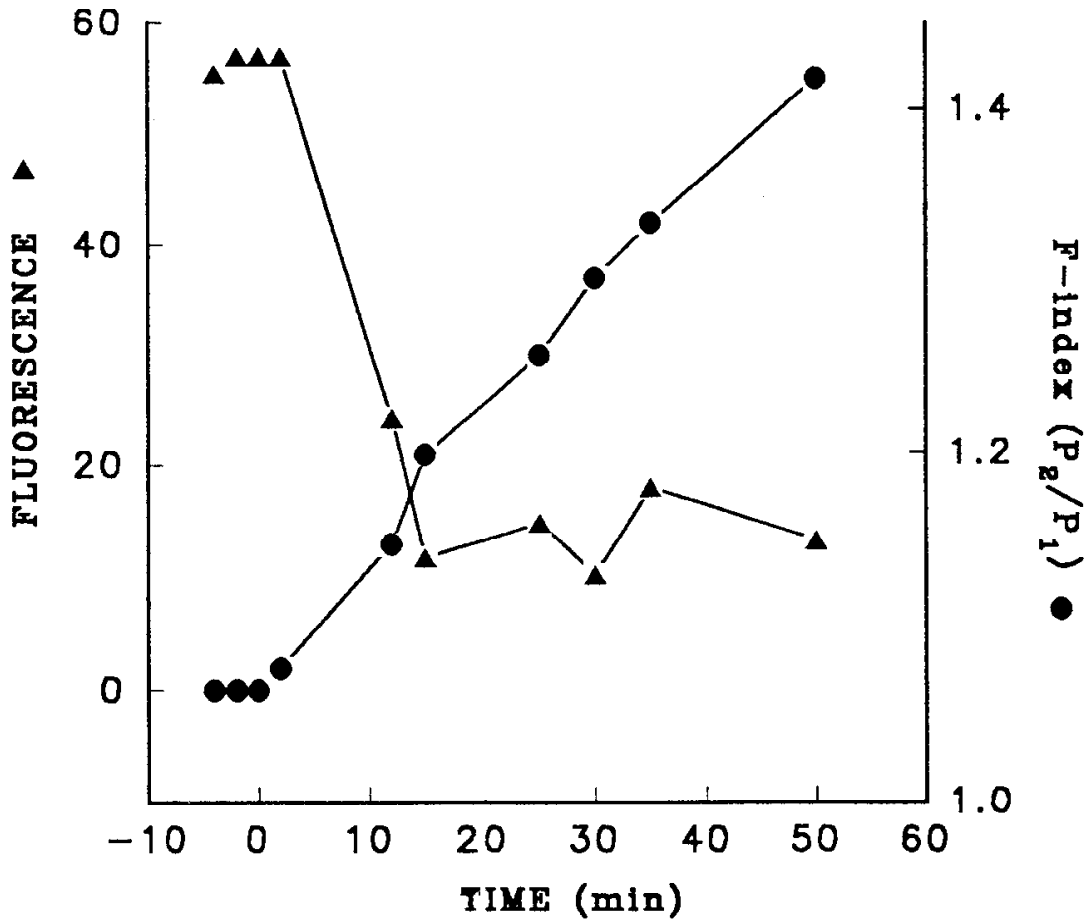

Figure 6. Injection of an exogenous $\mathrm{Ca}^{2+}$ buffer blocks outward current facilitation. Fluo-3 was injected iontophoretically into a voltage-clamped neuron from a microelectrode containing $1 \mathrm{~mm}$ dye dissolved in $100 \mathrm{~mm}$ HEPES (pH 7.8). A $10 \mathrm{nA}$ continuous injection current begins at time $=0$. The increase in dye concentration is plotted in units of fluorescence as a function of time during the injection (circles, left axis). Macropatch currents were recorded during paired $300 \mathrm{msec}$ pulses to $+15 \mathrm{mV}$ applied at a pulse interval of $1 \mathrm{sec}$ from a holding voltage of $-40 \mathrm{mV}$. The pulse sequence was repeated at successive time points before and during the fluo-3 injection. Values of $F$-index were calculated by dividing the outward current amplitude at the end of pulse 2 by the amplitude at the end of pulse 1 and plotted as a function of time (triangles, right axis). The macropatch was. located near the soma cap $\left(15^{\circ} \mathrm{C}\right.$, normal saline). at a rate of $1 /$ sec. It shows that the $\mathrm{Ca}^{2+}$ current inactivates with use and attains a final current waveform within five pulses. The peak $\mathrm{Ca}^{2+}$ current decreased by $40 \%$ during the pulse sequence while the current measured at the end of the pulse did not change. Figure $5 C$ illustrates the $I(V)$ curve for $\mathrm{Ca}^{2+}$ current constructed from measurements of peak current amplitude at a series of test voltages. These experiments provided no evidence of a use-dependent increase in $\mathrm{Ca}^{2+}$ current (see also Ahmed and Connor, 1979; Chad and Eckert, 1984; Thompson and Coombs, 1988; Johnson and Byerly, 1991; Fryer and Zucker, 1993). It is concluded that the facilitation of $I_{C}$ during repeated pulses does not result from a progressive increase in $\mathrm{Ca}^{2+}$ current. Instead, $I_{\mathrm{C}}$ facilitates despite $\mathrm{Ca}^{2+}$ current inactivation.

\section{Injected $\mathrm{Ca}^{2+}$ huffer blocks $\mathbf{I}_{\mathrm{C}}$ facilitation}

The facilitation of $I_{\mathrm{C}}$ during repeated pulses could result from a progressive accumulation of $\mathrm{Ca}^{2+}$ in the cytoplasm near the membrane. If this is so, it should be possible to reduce the value of $F$-index by injecting an appropriate calcium buffer into the cell (Adler et al., 1991). An experiment of this kind is illustrated in Figure 6. Macropatch currents were recorded during paired $300 \mathrm{msec}$ pulses to $+15 \mathrm{mV}$ from a holding voltage of -40 $\mathrm{mV}$. The pulse interval was one second. This sequence was repeated at successive time points during the iontophoretic injection of fluo-3 from a microelectrode containing $1 \mathrm{~mm}$ dye and $100 \mathrm{~mm}$ HEPES (pH 7.8; $10 \mathrm{nA}$ injection current). In this experiment fluo-3 is used as an exogenous, high-affinity, and mobile $\mathrm{Ca}^{2+}$ buffer. Figure 6 plots the relative increase in buffer concentration, measured from dye fluorescence, at the holding voltage as a function of time during the fluo- 3 injection and the value of $F$-index measured at the same time points. It shows that $F$-index decreases toward a value near 1 as the concentration of $\mathrm{Ca}^{2+}$ buffer increases. This result is taken as strong evidence that intracellular $\mathrm{Ca}^{2+}$ accumulation is required for outward current facilitation.
Variability in F-index between cells and between patches on the same cell

Whole-cell currents and macropatch currents were different in several respects. Inward $\mathrm{Na}^{+}$and $\mathrm{Ca}^{2+}$ currents were present in the whole-cell records but often absent in macropatch recordings. In some neurons the whole-cell outward current increased during repeated pulses, but in most experiments the outward current exhibited strong cumulative inactivation (Aldrich et al., 1979). Even when the whole-cell $\mathrm{K}^{+}$current inactivated, however, patches could readily be found that exhibited facilitation. When recording from multiple patches on such a cell, it was found that some patches showed outward current facilitation, others showed cumulative inactivation, and still others had intermediate bchavior. The data suggest that patches that are enriched in delayed-rectifier $\mathrm{K}^{+}$channels exhibit cumulative inactivation while those that are enriched in Ca-dependent $\mathrm{K}^{+}$ channels exhibit facilitation (see also Gola et al., 1990). It is apparent that outward currents recorded with whole-cell voltage-clamp methods represent the summed activity of an assortment of channel types and that the different channel types have a patchy, sometimes nonoverlapping distribution.

The value of $F$-index also varied between patches on the same neuron. In one example, 12 macropatches were sampled on the same cell. All of these patches exhibited outward current facilitation. Values of $F$-index were calculated for each patch after applying a series of ten $300 \mathrm{msec}$ pulses to $+10 \mathrm{mV}$ at a rate of $1 / \mathrm{sec}$. The range of values was $1.1-35.6$ (average $=7.2 \pm$ $9.7, \mathrm{SD}$ ), which indicates a very heterogeneous spatial distribution of this characteristic.

Local variability in $F$-index could result from local differences in $\mathrm{Ca}^{2+}$ accumulation due to the fact that $\mathrm{Ca}^{2+}$ channels tend to occur in clusters in the cell bodies of these neurons (Thompson and Coombs, 1988). To test this idea, $F$-index was measured as a function of $\mathrm{Ca}^{2+}$ current density. The experiments were 


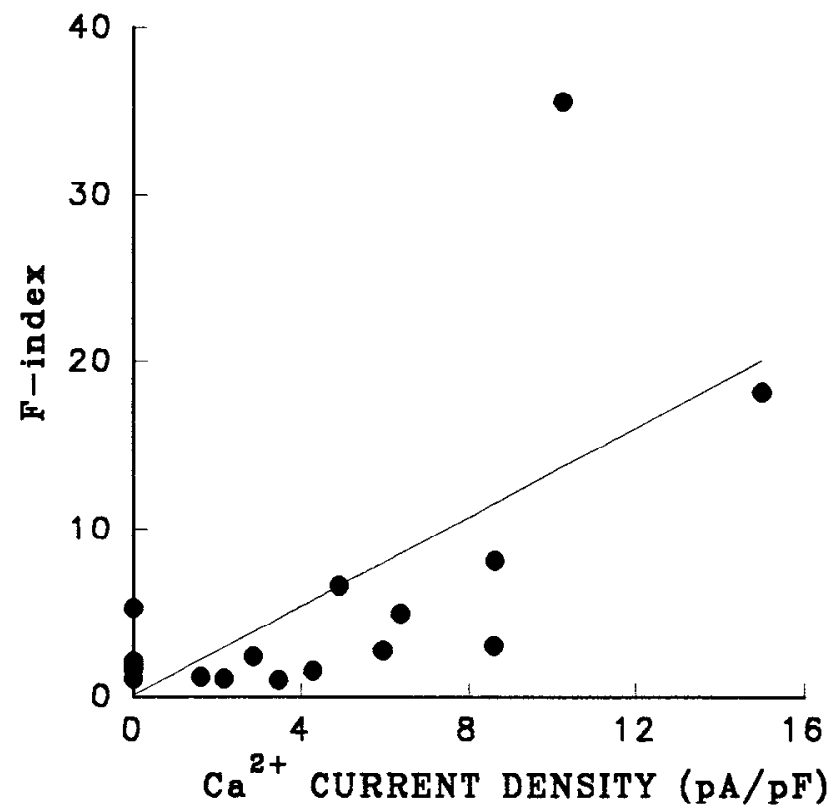

Figure 7. F-index as a function of $\mathrm{Ca}^{2+}$ current density in the patch (data from 18 patches on six neurons). An $\mathrm{Na}$-free external saline was used in these experiments to eliminate $\mathrm{Na}^{+}$currents (saline composition, mM: 450 Tris $\cdot \mathrm{Cl}, 10 \mathrm{KCl}, 10 \mathrm{CaCl}_{2}, 50 \mathrm{MgCl}_{2}, 10$ HEPES; pH 7.8 , $15^{\circ} \mathrm{C}$ ). $\mathrm{Ca}^{2+}$ currents were measured in each patch during a $50 \mathrm{msec}$ pulse to $+30 \mathrm{mV}$ from a holding voltage of $-40 \mathrm{mV}$ and current densities were calculated by dividing the maximum inward current amplitude by the area of the patch estimated from measurements of membrane capacitance using the method of Johnson and Thompson (1989). Values of $F$-index were calculated for each patch after applying a series of ten 300 msec pulses to $+15 \mathrm{mV}$ from a holding voltage of $-40 \mathrm{mV}$ (pulse rate $=1 \mathrm{~Hz}$ ) and dividing the amplitude of the outward current at the end of pulse 10 by the current amplitude at the end of pulse 1 . The solid line is a least-squares fit to the data points. The correlation is statistically significant (correlation coefficient $=0.67 ; P<0.01$ by $t$ tcst). Six of the 18 patches expressed $I_{C}$ facilitation when there was no measurable $\mathrm{Ca}^{2+}$ current.

done in $\mathrm{Na}$-free saline to eliminate $\mathrm{Na}^{+}$inward currents and the $\mathrm{Ca}^{2+}$ current density was calculated for each patch by dividing the maximum inward current during a $50 \mathrm{msec}$ test pulse to $+30 \mathrm{mV}$ by the area of the patch estimated from measurements of membrane capacitance (Johnson and Thompson, 1989). This provides a reasonably good estimate of $\mathrm{Ca}^{2+}$ current density because $\mathrm{Ca}^{2+}$ currents activate more rapidly than contaminating $\mathrm{K}^{+}$currents. $F$-index was calculated for the same patches after applying a series of 10 pulses to $+15 \mathrm{mV}$ and this experiment was repeated for a total of 18 patches from six cells. $F$-index is plotted as a function of $\mathrm{Ca}^{2+}$ current density in Figure 7. The solid line is a least-squares fit to the data and the correlation is statistically significant $(P<0.01, t$ test). Twelve of the patches expressed measurable $\mathrm{Ca}^{21}$ current. In one macropatch the value of $F$-index and the $\mathrm{Ca}^{2+}$ density were both relatively large, suggesting that the electrode sampled a region where $\mathrm{Ca}^{2+}$ channels and $I_{\mathrm{C}}$ channels were located close together. In six other patches, however, outward current facilitation was observed when there was no measurable $\mathrm{Ca}^{2+}$ current and this includes one patch in which the value of F-index (5.3) approached the mean value for the entire data set (5.5). These results show that $I_{C}$ facilitation is correlated with the local $\mathrm{Ca}^{2+}$ channel density but they also show that $I_{\mathrm{C}}$ channels and $\mathrm{Ca}^{2+}$ channels do not have to reside in the same macropatch for facilitation to occur. It is apparent that facilitation is not re- stricted to $\mathrm{Ca}^{2+}$ domains immediately adjacent to $\mathrm{Ca}^{2+}$ channels and that it also occurs when $\mathrm{Ca}^{2+}$ accumulates in the region of the patch after entering that region by diffusing from the surround.

Measurements of $\mathrm{Ca}^{2+}$ accumulation near the membrane with fluo-3 imaging

The $\mathrm{Ca}^{2+}$ indicator fluo-3 was used in fluorescence imaging experiments to measure the amplitude and time course of the change in $[\mathrm{Ca}]_{i}$ near the membrane and at locations deeper in the cytoplasm during repeated voltage-clamp steps. Figure $8 \mathrm{~A}$ illustrates the change in $[\mathrm{Ca}]_{i}$ during a series of 10 pulses to +15 $\mathrm{mV}$ in three regions of interest, each $2 \mu \mathrm{m}$ in width and $20 \mu \mathrm{m}$ in length. The first region of interest was drawn along the circumference of the cell as viewed from the top and emphasizes the $\mathrm{Ca}^{2+}$ signal at the membrane. In this region, each voltageclamp pulse results in a transient increment in $[\mathrm{Ca}]_{i}$. The increments decrease slightly in amplitude during the pulse train but each increment adds to a progressive accumulation of $[\mathrm{Ca}]_{i}$. The change in $[\mathrm{Ca}]_{i}$ at the membrane recovers slowly after the last pulse in the train with a half-recovery time of $5 \mathrm{sec}$ in this example. The average half-recovery time for $[\mathrm{Ca}]_{i}$ in the region adjacent to the membrane was $8.4 \pm 4.5 \mathrm{sec}( \pm \mathrm{SD}, n=9)$ at $15^{\circ} \mathrm{C}$.

Calcium accumulation was also measured in $2-\mu \mathrm{m}$-thick regions of interest positioned $10 \mu \mathrm{m}$ and $30 \mu \mathrm{m}$ from the edge of the cell during the same pulse train. The fluorescence signals in these regions emphasize the change in $[\mathrm{Ca}]_{i}$ deeper in the cytoplasm, but because conventional fluorescence imaging was used, they also include contributions from volume elements that are above and below the plane of focus, including contributions from near membrane regions at the top and bottom of the cell (see Müller et al., 1993). Figure $8 A$ shows that the increments in $[\mathrm{Ca}]_{i}$ associated with voltage-clamp pulses are less pronounced deeper in the cytoplasm and that $\mathrm{Ca}^{2+}$ accumulation is attenuated with distance from the membrane. The shell model was used to simulate this recording situation. Figure $8 B$ illustrates the predicted $\mathrm{Ca}^{2+}$ accumulation in a 1- $\mu \mathrm{m}$-thick region of cytoplasm located at the membrane, the average signal in the outer $10 \mu \mathrm{m}$ of cytoplasm, and the average signal in the outer $30 \mu \mathrm{m}$ of cytoplasm. The predictions approximate what is seen experimentally: $[\mathrm{Ca}]_{i}$ transients associated with each pulse and the overall accumulation of $\mathrm{Ca}^{2+}$ are greatest near the membrane and decreasc in amplitude in a gradicnt from the membranc toward the center of the cell.

\section{Simulation of $\mathrm{Ca}^{2+}$ accumulation and $\mathrm{I}_{C}$ facilitation}

The shell model was used to simulate $\mathrm{Ca}^{2+}$ currents, intracellular $\mathrm{Ca}^{2+}$ accumulation, and Ca-dependent $\mathrm{K}^{+}$currents during repeated pulses. Figure $9 A$ shows the predicted changes in $[\mathrm{Ca}]_{t}$ in a $1-\mu \mathrm{m}$-thick shell located at the membrane during five 300 msec pulses to $+15 \mathrm{mV}$ using three different values for the $\mathrm{Ca}^{2+}$ buffer concentration: 3, 30, and $300 \mu \mathrm{M}$. Each pulse results in an incremental increase in $[\mathrm{Ca}]_{i}$ and the increments build upon a progressive $[\mathrm{Ca}]_{i}$ accumulation. The $\mathrm{Ca}^{2+}$ buffer concentration has a large effect on the change in $[\mathrm{Ca}]_{i}$ during the pulse series and the time course of recovery of $[\mathrm{Ca}]_{i}$ after the series. Increasing the buffer concentration reduces $[\mathrm{Ca}]_{i}$ accumulation at the membrane, reduces the amplitude of $[\mathrm{Ca}]_{i}$ transients and the progressive increase in transients during successive pulses, and slows the time course of $[\mathrm{Ca}]_{i}$ recovery.

The simulation with $30 \mu \mathrm{M} \mathrm{Ca}$ buffer was used to predict the 


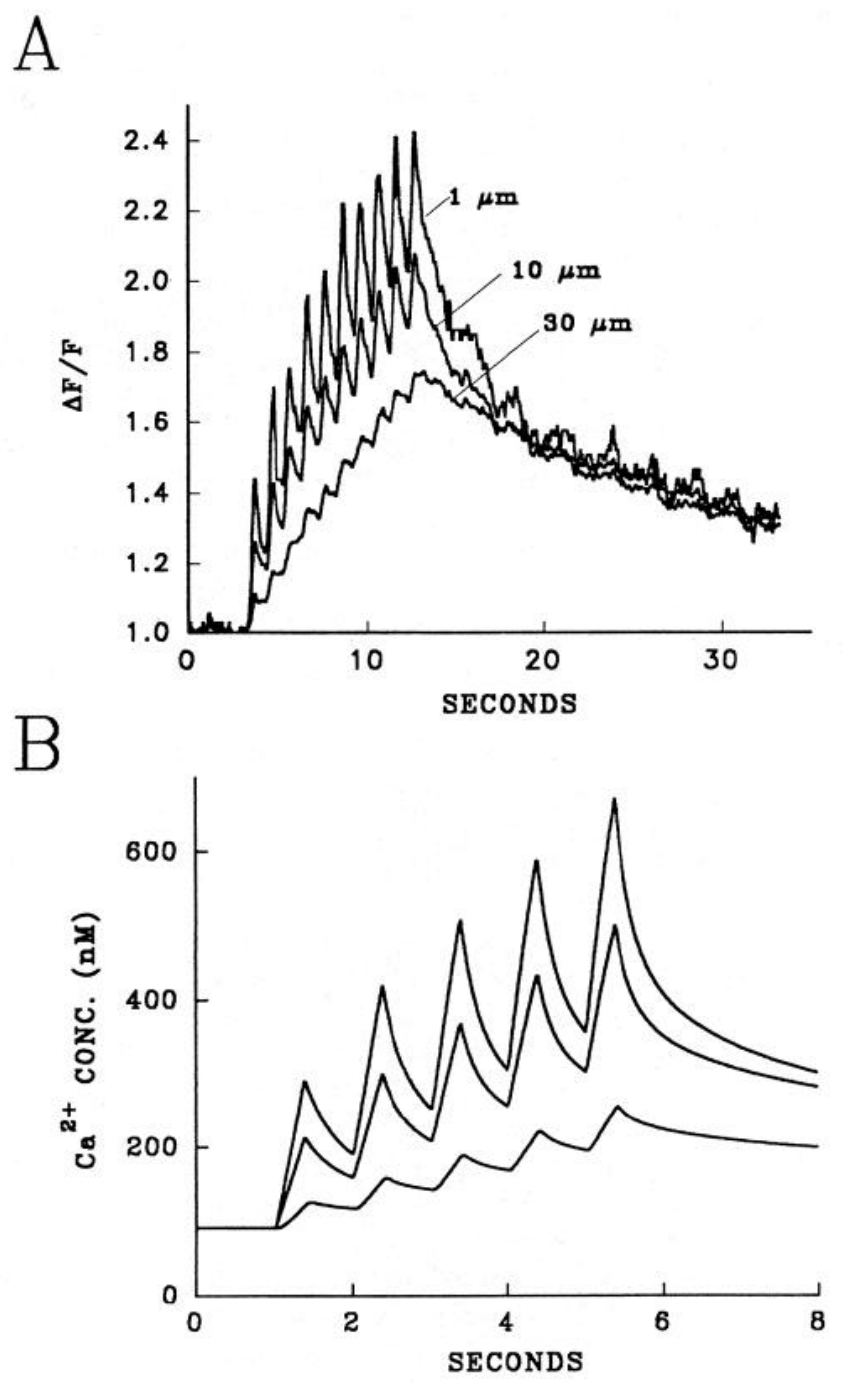

Figure 8. $\mathrm{Ca}^{2+}$ accumulation during repeated depolarizing pulses measured with fluo-3 imaging. $A, \mathrm{Ca}^{2+}$ accumulation in three regions of interest, each $2 \mu \mathrm{m}$ in thickness and $20 \mu \mathrm{m}$ in length drawn along the circumference of the cell body as viewed from the top, $10 \mu \mathrm{m}$ from the edge of the cell, and $30 \mu \mathrm{m}$ from the edge. The neuron cell body was roughly spherical and $230 \mu \mathrm{m}$ in diameter. A series of 10 voltage-clamp pulses was presented from a holding voltage of $-40 \mathrm{mV}$ to a test voltage of $+15 \mathrm{mV}$. The pulse interval was $1 \mathrm{sec}$. Results are plotted in units of fluorescence intensity $(\Delta F / F)$ as a function of time. $B$, Time course of $\mathrm{Ca}^{2+}$ accumulation predicted by the shell model. Three solutions are illustrated, corresponding to the change in $[\mathrm{Ca}]_{i}$ in a $1-\mu \mathrm{m}$-thick shell located at the membrane, the change in $[\mathrm{Ca}]_{i}$ averaged across the outer $10 \mu \mathrm{m}$ of cytoplasm, and the average change in $[\mathrm{Ca}]_{i}$ in the outer 30 $\mu \mathrm{m}$ (cell radius $=150 \mu \mathrm{m} ; \mathrm{Ca}^{2+}$ buffer concentration $=30 \mu \mathrm{M} ; k_{e}=3.0$ $\left.\times 10^{-3} \mathrm{~cm} / \mathrm{sec}\right)$.

amplitudes and time courses of $\mathrm{Ca}^{2+}$ currents and Ca-dependent $\mathrm{K}^{+}$currents during the same pulse series. Figure $9 B$ shows calcium current and $I_{\mathrm{C}}$ on the same time scale. Each pulse results in an identical $\mathrm{Ca}^{2+}$ current but $I_{\mathrm{C}}$ grows in amplitude during the pulse train and this is accompanied by a progressive increase in instantaneous outward current. Outward current facilitation is a robust prediction of the model and it is apparent that the time course of facilitation follows the time course of $[\mathrm{Ca}]_{i}$ accumulation near the membrane.

Fluo-3 fluorescence imaging was used to measure $\mathrm{Ca}^{2+}$ accumulation in a $2-\mu \mathrm{m}$-thick, $10-\mu \mathrm{m}$-long region of interest drawn
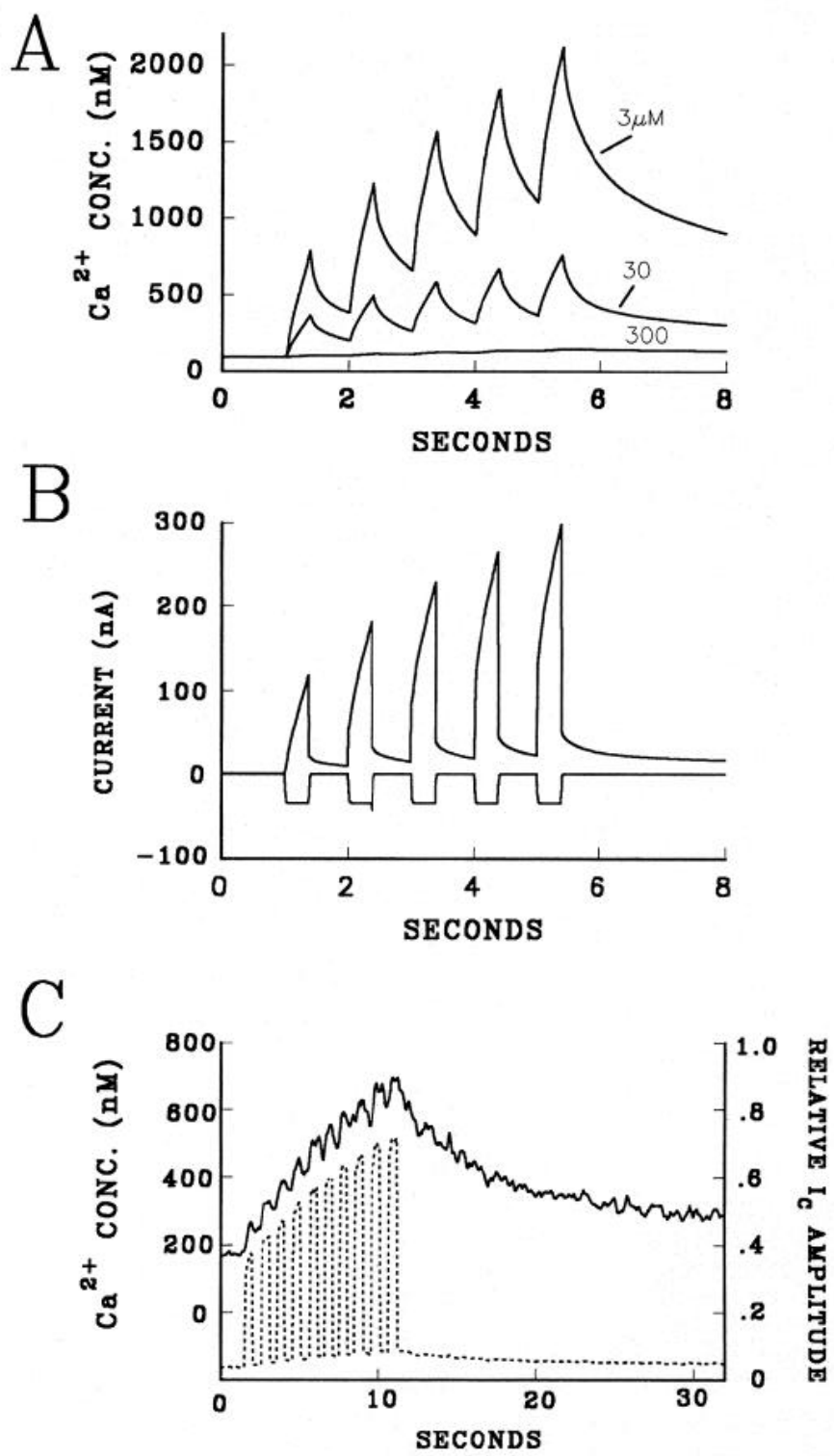

Figure 9. Predictions of $\mathrm{Ca}^{2+}$ accumulation and $I_{C}$ facilitation from the shell model. A, Predicted time course of $\mathrm{Ca}^{2+}$ accumulation in a $1-\mu \mathrm{m}$-thick shell of cytoplasm adjacent to the membrane during five $300 \mathrm{msec}$ voltage-clamp pulses to $+10 \mathrm{mV}$ applied at a rate of $1 / \mathrm{sec}$. The change in $[\mathrm{Ca}]_{i}$ was calculated for three concentrations of $\mathrm{Ca}^{2+}$ buffer; 3,30 , and $300 \mu \mathrm{M} . \mathrm{B}, \mathrm{Ca}^{2+}$ currents (shown as negative currents) and Ca-dependent $\mathrm{K}^{+}$currents (positive currents) predicted from the model during the same pulse train assuming $\mathrm{a} \mathrm{Ca}^{2+}$ buffer concentration of $30 \mu \mathrm{M}$. $C$, Fluo-3 fluorescence imaging and digital image processing was used to measure $\mathrm{Ca}^{2+}$ accumulation in a $2-\mu \mathrm{m}$-thick, $10-\mu \mathrm{m}$-long region of interest adjacent to the cell membrane during a series of ten $300 \mathrm{msec}$ pulses to $+15 \mathrm{mV}$ applied at a rate of $1 / \mathrm{sec}$ from a holding voltage of $-40 \mathrm{mV}$. The fluorescence signal was converted to units of $[\mathrm{Ca}]_{i}$ as described in Materials and Methods and this measurement was used to simulate the time course of $I_{\mathrm{C}}$ during the pulse series assuming the characterization of $I_{\mathrm{C}}$ gating described in Materials and Methods. The time course of $[\mathrm{Ca}]_{i}$ is shown in the upper trace (left vertical scale) and the time course of $I_{C}$ is shown in the lower trace (dotted line, right vertical scale). The predicted value of $F$-index was 2.1 and was obtained by dividing the maximum amplitude of the simulated current during pulse 10 by the maximum amplitude during pulse 1 .

along the cytoplasmic edge of the cell body during a train of ten $300 \mathrm{msec}$ pulses to $+15 \mathrm{mV}$ from a holding voltage of -40 $\mathrm{mV}$. The measurements were calibrated in units of $[\mathrm{Ca}]_{i}$ and used to predict the time course of $I_{\mathrm{C}}$ assuming the same two- 
state gating scheme for $I_{\mathrm{C}}$ activation that was applied in the shell model. The result is plotted in Figure $9 C$, and it shows that the cxpcrimentally measured change in $[\mathrm{Ca}]_{i}$ predicts $I_{\mathrm{C}}$ facilitation with an $F$-index of 2.1 and a progressive increase in instantaneous outward current with successive pulses. These changes occur despite the fact that the increments in $[\mathrm{Ca}]_{i}$ associated with the individual voltage-clamp steps decrease in amplitude during the stimulus train. The results of this analysis support the conclusion that $I_{\mathrm{C}}$ facilitation depends on $\mathrm{Ca}^{2+}$ accumulation and not on a use-dependent increase in the amplitude of individual $\mathrm{Ca}^{2+}$ transients.

\section{Effect of temperature on $\mathrm{F}$-index}

$I_{\mathrm{C}}$ facilitation is reduced at higher temperatures. Figure $10, \mathrm{~A}$ and $B$, shows outward currents recorded from the same macropatch at two temperatures, $15^{\circ} \mathrm{C}$ and $25^{\circ} \mathrm{C}$, during a series of ten 300 msec pulses to $+15 \mathrm{mV}$ applied at $1 \mathrm{~Hz}$ from a holding voltage of $-40 \mathrm{mV}$. At the higher temperature the outward current activates more rapidly but facilitation is lcss pronounced and the current reaches a saturating amplitude in fewer pulses. At $15^{\circ} \mathrm{C}$ the value of $F$-index was 2.5 while at $25^{\circ} \mathrm{C}$ the value was 1.9. In fluo-3 imaging experiments, it was found that raising the temperature from $15^{\circ} \mathrm{C}$ to $25^{\circ} \mathrm{C}$ leads to a faster recovery of $[\mathrm{Ca}]_{i}$ back to the resting level after the pulse train (Fig. 10C). This was observed in each of three experiments where the average half-recovery decreased from $13.7 \pm 6.2 \mathrm{sec}$ at $15^{\circ} \mathrm{C}$ to $7.4 \pm 5.6 \mathrm{sec}$ at $25^{\circ} \mathrm{C}$. These findings suggest that $\mathrm{Ca}^{2+}$ removal by active transport is more efficient at the higher temperature, and this could explain the affect of elevated temperature on $F$-index since an accelerated rate of $\mathrm{Ca}^{2+}$ clearance is expected to reduce $\mathrm{Ca}^{2+}$ accumulation. It was not possible to test this idea directly with fluo-3 because the dissociation constant of the dye is temperature sensitive (Merritt et al., 1990), and it was not possible to calibrate dye signals at two temperatures in a single neuron because the calibration procedure is destructive. The shell model was used to simulate the effect of elevated temperature by increasing the value of $k_{e}$, the rate constant for $\mathrm{Ca}^{2+}$ efflux (Fig. 10D). A 10-fold increase in this rate constant predicts a reduction in the amplitude of $[\mathrm{Ca}]_{i}$ increments associated with each pulse, reduced growth of $[\mathrm{Ca}]_{i}$ increments during successive pulses, and reduced $[\mathrm{Ca}]_{i}$ accumulation in the outer shell. The predictions are consistent with the hypothesis that the effect of increased temperature on $F$-index results from an increase in the rate of $\mathrm{Ca}^{2+}$ pumping either into cytoplasmic organelles or across the cell membrane.

\section{Importance of $\mathrm{Na} / \mathrm{Ca}$ exchange to $\mathbf{I}_{\mathrm{C}}$ facilitation}

$\mathrm{Na} / \mathrm{Ca}$ counter transport limits $[\mathrm{Ca}]_{i}$ accumulation and $I_{\mathrm{C}}$ facilitation during repeated pulses. Figure $11, A$ and $B$, shows membrane currents during a series of ten $300 \mathrm{msec}$ pulses to $+15 \mathrm{mV}$ recorded from the same macropatch under two conditions. Recordings were first made in normal saline. The bath volume was then exchanged for an $\mathrm{Na}$-free, Tris-substituted saline in order to block $\mathrm{Na} / \mathrm{Ca}$ exchange (Requena, 1983), and the pulse series was repeated. The figures show that outward current facilitation is much greater when the cell is bathed in $\mathrm{Na}$-free saline $(F$-index in normal saline $=2.3 ; F$-index in $\mathrm{Na}$ free saline $=7.5$ ). During the first few pulses of the series the outward current reached approximately the same amplitude in both salines, but $I_{\mathrm{C}}$ facilitation became much more pronounced during later pulses when $\mathrm{Na} / \mathrm{Ca}$ exchange was blocked. Fluo-3 imaging was used to measure the change in $[\mathrm{Ca}]_{i}$ in a $2-\mu \mathrm{m}-$ thick region of interest adjacent to the cell membrane under the same conditions. Figure $11, C$ and $D$, shows $[\mathrm{Ca}]_{i}$ transients during single depolarizing pulses and during trains of five pulses recorded from the same region of interest in normal saline and in $\mathrm{Na}$-free saline. Exposure to $\mathrm{Na}$-free saline increased the resting [Ca $]_{i}$ by approximately $80 \mathrm{nM}$. During a single depolarizing pulse, the change in fluo- 3 fluorescence reached the same maximum value in both salines, but it is apparent that $[\mathrm{Ca}]_{i}$ recovered more slowly when $\mathrm{Na} / \mathrm{Ca}$ exchange was blocked (Fig. $11 \mathrm{C}$ ). During the train of five pulses, $\mathrm{Ca}^{2+}$ accumulation was much more pronounced in $\mathrm{Na}$-free saline and the decrease in recovery rate was more apparent (Fig. $11 D$ ). This experiment was repeated four times and the average half-recovery time increased from $4.2 \pm 1.1( \pm \mathrm{SD}) \mathrm{sec}$ to $9.4 \pm 4.5 \mathrm{sec}$ when $\mathrm{Na} / \mathrm{Ca}$ exchange was blocked. These results show that under normal conditions, the $\mathrm{Na} / \mathrm{Ca}$ exchange mechanism is effective in limiting $\mathrm{Ca}^{2+}$ accumulation near the membrane and $I_{\mathrm{C}}$ facilitation.

\section{Discussion}

Outward currents recorded from selected macropatches facilitate when depolarizing voltage-clamp pulses are presented at rates as low as $1 / \mathrm{sec}$. Facilitation is characterized by a progressive increase in the amplitude of the outward current toward a saturating value, an increase in the instantaneous outward current during successive pulses, and a decrease in utilization time. The change in the $I(V)$ curve during facilitation, the voltage dependence of $F$-index, and the effect of injected $\mathrm{Ca}^{2+}$ buffer on $F$-index are taken as strong evidence that facilitation results from intracellular $\mathrm{Ca}^{2+}$ accumulation subsequent to the activation of voltage-dependent $\mathrm{Ca}^{2+}$ channels and that $I_{C}$ is the facilitating species. Recovery from facilitation follows approximately the same time course as the decay of $[\mathrm{Ca}]_{i}$ measured with fluo-3 in regions of interest near the membrane. It also follows the time course of the $I_{\mathrm{C}}$ tail current after a depolarizing voltagc-clamp pulse (Gorman and Thomas, 1980; Barish and Thompson, 1983; Thompson et al., 1986; Smith and Thompson, 1987; Lando and Zucker, 1989). From these observations we conclude that the dynamics of $[\mathrm{Ca}]_{i}$ accumulation and recovery at the membrane determine the dynamics of $I_{C}$ facilitation. Strong evidence in support of this comes from experiments using $\mathrm{Na}$-free saline to block $\mathrm{Na} / \mathrm{Ca}$ exchange, a treatment that increases both $\mathrm{Ca}^{2+}$ accumulation and $F$-index (see also Meiri et al., 1986; Mulkey and Zucker, 1992).

There have been several reports documenting the facilitation of $\mathrm{Ca}^{2+}$-dependent $\mathrm{K}^{+}$current during repeated voltage-clamp pulses in molluscan neurons, but there are substantial differences between the results of the present study and these earlier reports. In their studies of Helix neurons, Lux and Hofmeier (1982), Gola et al. (1990), and Gola and Crest (1993) found that depolarizing prepulses sufficient to activate $\mathrm{Ca}^{2+}$ current accelerated the activation of potassium current but facilitated $\mathrm{K}^{+}$currents reached the same maximum amplitude as control currents. To explain this result Gola and Crest (1993) suggested that $I_{C}$ channels are activated only if they are located near $\mathrm{Ca}^{2+}$ channels in $\mathrm{Ca}^{2+}$ domains that they viewed as nonoverlapping, discrete volumes in which substantial $\mathrm{Ca}^{2+}$ accumulation occurs. $I_{\mathrm{C}}$ channels that are not near $\mathrm{Ca}^{2+}$ domains were thought to represent a subset of cryptic channels that remain inactive under physiological conditions. This is not the case in Doriopsilla neurons, where $I_{\mathrm{C}}$ facilitation is characterized by both a decrease in utilization time and a large increase in outward current amplitude toward a saturating value. The results from numerical 
A

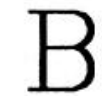

$50 \mathrm{msec}$

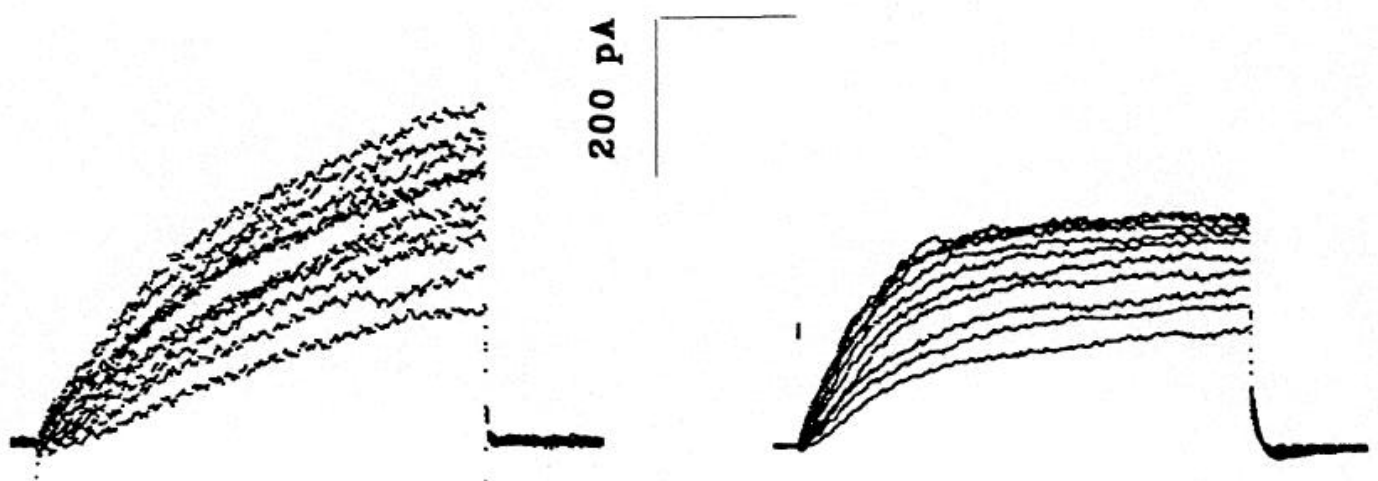

C
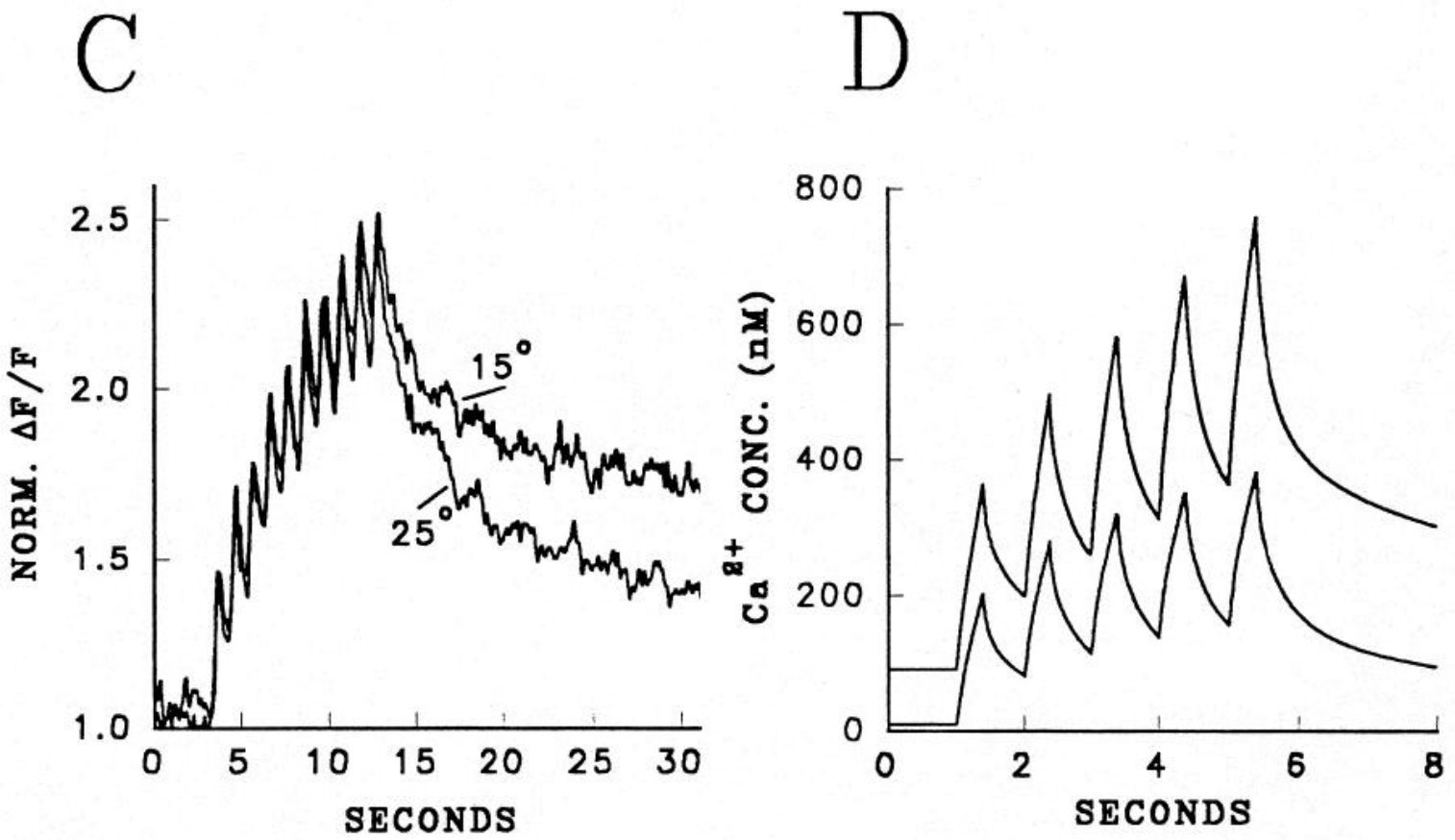

Figure 10. Effect of temperature on $I_{C}$ facilitation. A, Patch currents during a series of ten $300 \mathrm{msec}$ pulses to $+15 \mathrm{mV}$ from a holding voltage of $-40 \mathrm{mV}$ at a temperature of $15^{\circ} \mathrm{C} . B$, Currents recorded from the same macropatch when the pulse series was repeated 10 min after warming the preparation to $25^{\circ} \mathrm{C}$. $C$, Fluo-3 imaging was used to measure the time course of $[\mathrm{Ca}]_{i}$ accumulation in a $2-\mu \mathrm{m}-$ thick, $10-\mu \mathrm{m}-\mathrm{long}$ region of interest at the edge of the cell during the same pulse series. This measurement was repeated at $15^{\circ} \mathrm{C}$ and $10 \mathrm{~min}$ after warming to $25^{\circ} \mathrm{C}$. The fluorescence records were normalized to the same maximum amplitude, and it is seen that $[\mathrm{Ca}]_{i}$ recovers more rapidly at the higher temperature. $D$, Time course of $[\mathrm{Ca}]_{i}$ in the outer $1 \mu \mathrm{m}$ of cytoplasm predicted by the shell model using two values of $k_{e}$ the rate constant for Ca ${ }^{2+}$ active transport. $\mathrm{Ca}^{2+}$ accumulation is reduced when $k_{e}$ is increased by a factor of 10 (from $3.0 \times 10^{-3}$ to $30.0 \times 10^{-3} \mathrm{~cm} / \mathrm{sec}$ ).

modeling show that decreased latency and increased current amplitude are expected if facilitation is caused by progressive $\mathrm{Ca}^{2+}$ accumulation in the vicinity of $\mathrm{Ca}^{2+}$-dependent $\mathrm{K}^{+}$channels and if the sole effect of $\mathrm{Ca}^{2+}$ accumulation is to increase the probability of channel opening (Chagneux et al., 1989; Ikemoto et al., 1989). This result obtains when there is an excess of $I_{\mathrm{C}}$ channels, and it is independent of whether $\mathrm{Ca}^{2+}$ channels and $I_{\mathrm{C}}$ channels are clustered together or widely spaced, as long as $\mathrm{Ca}^{2+}$ can reach $\mathrm{Ca}^{2+}$-dependent $\mathrm{K}^{+}$channels by diffusion.

There is evidence that $\mathrm{Ca}^{2+}$ channels and $\mathrm{Ca}$-dependent $\mathrm{K}^{+}$ channels are colocalized in some preparations (Chad and Eckert, 1984; Gola et al., 1990; Roberts et al., 1990). In the present study there was a significant correlation between $\mathrm{Ca}^{2+}$ current density and the value of $F$-index. However, $I_{\mathrm{C}}$ facilitation was 


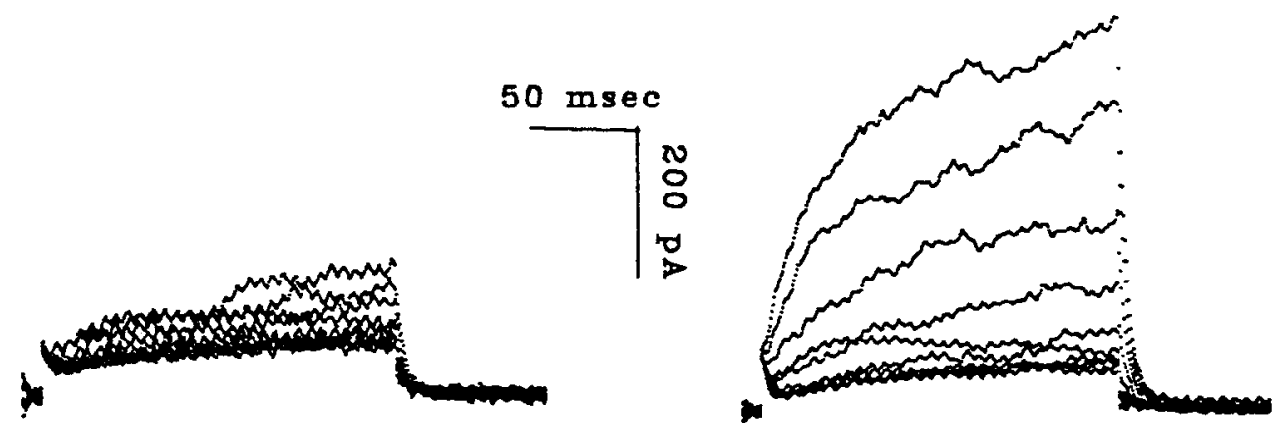

B
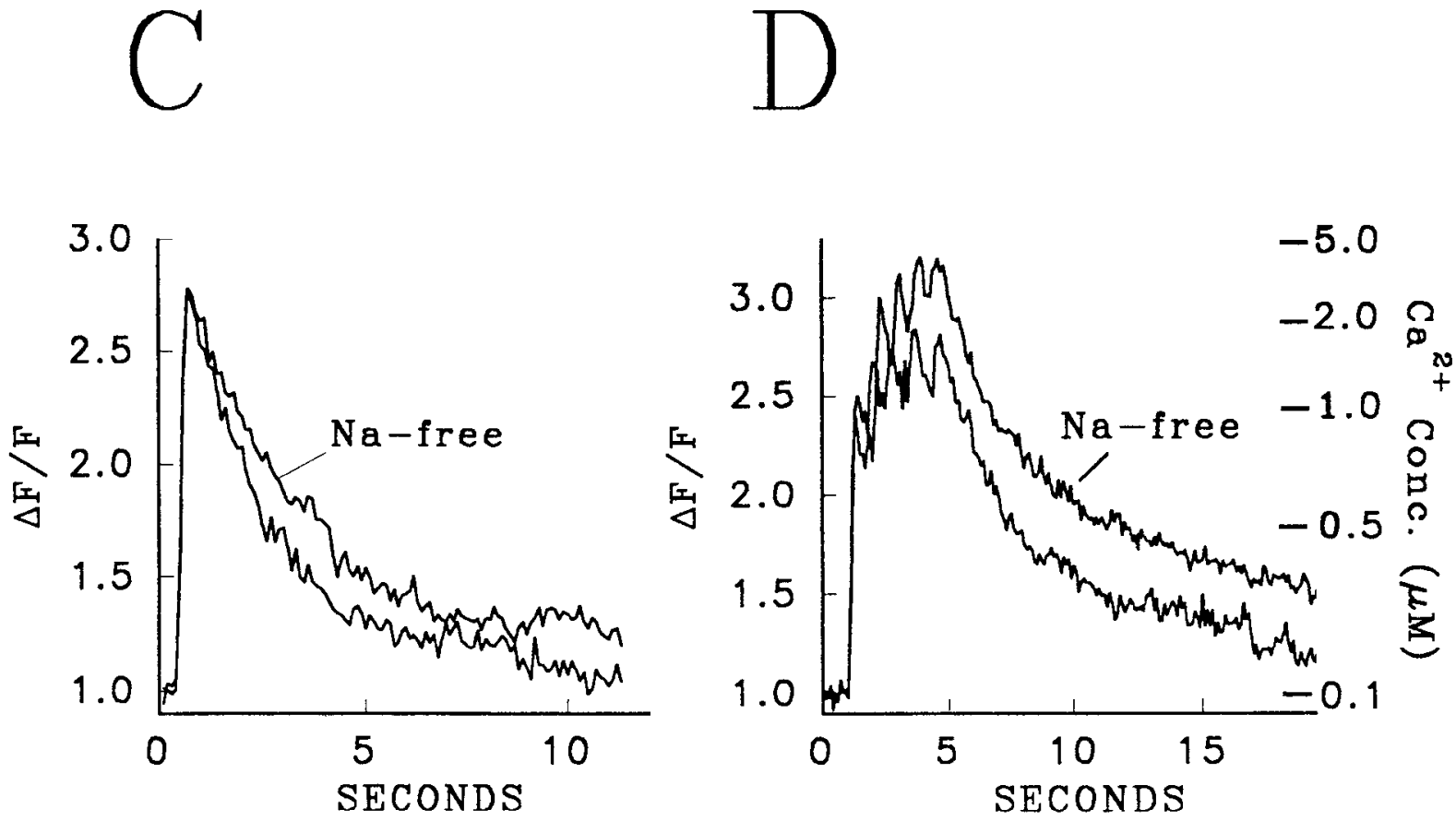

Figure 11. Effect of blocking $\mathrm{Na} / \mathrm{Ca}$ exchange on $I_{\mathrm{C}}$ facilitation and $\mathrm{Ca}^{2+}$ accumulation. $A$, Macropatch currents recorded in normal saline during a series of ten $300 \mathrm{msec}$ pulses to $+15 \mathrm{mV}$ from a holding voltage of -40 repeated at $1 \mathrm{~Hz}$ (macropatch located at the soma cap). $B$, Currents recorded from the same macropatch after exchanging the bath volume for an Na-free saline containing $(\mathrm{mM}) 450 \mathrm{Tris} \cdot \mathrm{Cl}, 10 \mathrm{KCl}, 10 \mathrm{CaCl}, 50$

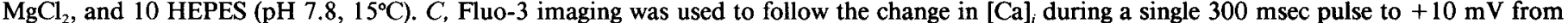
a holding voltage of $-40 \mathrm{mV}$ first in normal saline and after exchanging the bath volume for $\mathrm{Na}$-free saline. The image processor was used to measure fiuorescence signals in a $2-\mu \mathrm{m}$-thick, $20-\mu \mathrm{m}$-long region of interest located at the membrane. Results âre plotted in units of normalized fluorescence intensity $(\Delta F / F) . D, \mathrm{Ca}^{2+}$ accumulation in the same region of interest during a train of five $300 \mathrm{msec}$ pulses to $+10 \mathrm{mV}$ recorded in normal saline and in Na-free saline. Results are plotted both as $\Delta F / F$ and in units of [Ca] following the calibration procedure in Materials and Methods.

frequently observed when there was no measurable $\mathrm{Ca}^{2+}$ current in the patch and for these cases it must be concluded that $\mathrm{Ca}^{2+}$ accumulated in the region of the patch after diffusing from the surround. It is expected that with time, calcium domains near open $\mathrm{Ca}^{2+}$ channels will merge into macrodomains and then into $\mathrm{Ca}^{2+}$ gradients on an increasing spatial scale due to diffusion. The present results show that $\mathrm{Ca}^{2+}$-dependent $\mathrm{K}^{+}$channels that are not located near $\mathrm{Ca}^{2+}$ channels can be recruited by this mechanism during repeated pulses. This makes the concept of cryptic $I_{\mathrm{C}}$ channels rather cumbersome since it has more to do with the frequency of depolarization and the length of depolarizing trains than with restricted diffusional compartments.

Gola et al. (1990) provided information relevant to the fusion of $\mathrm{Ca}^{2+}$ domains with time. They showed that $\mathrm{Ca}^{2+}$ from the surround induced delayed $\mathrm{K}^{+}$channel openings in patches with a lag time of $50-80 \mathrm{msec}$ and that peak opening probability 
occurred 300-400 msec after a brief $\mathrm{Ca}^{2+}$ entry. They equated this delay with a diffusion distance of 5-8 $\mu \mathrm{m}$ from open $\mathrm{Ca}^{2+}$ channels to $\mathrm{Ca}$-dependent $\mathrm{K}^{+}$channels. The present results are in basic agreement with their findings. In Figure $1 C$, for example, there is no detectable inward current in the patch and the delay between the onset of the first depolarizing pulse and the appearance of outward current is about $50 \mathrm{msec}$. The delay becomes progressively shorter as the pulse is repeated, which is consistent with the idea that $\mathrm{Ca}^{2+}$ enters the region of the patch by diffusion and accumulates in that region during repeated pulses.

Few studies have attempted to resolve the change in $[\mathrm{Ca}]_{i}$ at the membrane during repeated depolarizations. Smith and Zucker (1980) used the photoprotein aequorin to measure $[\mathrm{Ca}]_{i} \operatorname{tran}-$ sients and showed that the aequorin response facilitates. Because $\mathrm{Ca}^{2+}$ binding to this protein is highly cooperative, it was concluded that facilitation of the aequorin signal is due to $\mathrm{Ca}^{2+}$ accumulation during the pulse train and not due to facilitation of $\mathrm{Ca}^{2+}$ concentration increments. The present experiments on facilitation of $I_{\mathrm{C}}$, which is a linear indicator of $[\mathrm{Ca}]_{i}$ at the membrane in this preparation, are consistent with this interpretation.

In the present study, fluo-3 fluorescence imaging was used to measure $\mathrm{Ca}^{2+}$ accumulation during repeated pulses in regions of interest $2 \mu \mathrm{m}$ in thickness drawn at the periphery of the cytoplasm. Calcium accumulation in this region and $I_{\mathrm{C}}$ facilitation follow approximately the same time course, which supports the conclusion that progressive $\mathrm{Ca}^{2+}$ accumulation is the cause of $I_{\mathrm{C}}$ facilitation. The fluo-3 results exhibit several of the behaviors predicted by the shell model: the $[\mathrm{Ca}]_{i}$ change near the membrane has a transient component associated with each voltage-clamp pulse and the increments are less evident and $\mathrm{Ca}^{2+}$ accumulation is delayed and less pronounced in more interior regions of the cell (see also Blumenfeld et al., 1992). Experimental measurements of $\mathrm{Ca}^{2+}$ accumulation near the membrane predict $I_{\mathrm{C}}$ facilitation when one assumes a two-state model for $I_{C}$ channel gating and a linear $\mathrm{Ca}$ dependence. Moreover, the degree of facilitation predicted by the model is similar to what is seen in voltage-clamp experiments.

The fluo- 3 imaging experiments leave some questions unresolved, however. The data suggest that the increments in $[\mathrm{Ca}]_{i}$ near the membrane contributed by successive voltage pulses decrease in amplitude during a pulse train. Interpretation of this result is complicated by the limited temporal and spatial resolution of the video imaging method and by the fact that the dye approaches saturation in the region of interest. Because of these limitations, it is likely that the method underestimates the change in $[\mathrm{Ca}]_{i}$ in small volume elements adjacent to the membrane where $\mathrm{K}^{+}$channels reside (see Blumenfeld et al., 1992; Nowycky and Pinter, 1993). Accurate correction for dye saturation was difficult and for this reason it was not possible to determine whether $[\mathrm{Ca}]_{i}$ transients at the membranc truly dccrease with use, which might be expected from $\mathrm{Ca}^{2+}$ current inactivation, or whether they grow in amplitude due, for example, to saturation of local $\mathrm{Ca}^{2+}$ buffers. Numerical modeling cannot resolve this question but the modeling studies do show that the amplitude of $[\mathrm{Ca}]_{i}$ increments and the growth of $[\mathrm{Ca}]_{i}$ increments during repeated pulses are reduced when the $\mathrm{Ca}^{2+}$ buffer concentration is raised. Blumenfeld et al. (1992) illustrated a similar effect.

The strength of $I_{\mathrm{C}}$ facilitation varies between patches on the same neuron. The cause of this variability is not yet resolved but it is apparent that the whole-cell potassium current is the sum of contributions from membrane patches with quite different facilitation properties. One possible explanation for regional variability in $F$-index is that local $[\mathrm{Ca}]_{i}$ hot spots develop near clusters of $\mathrm{Ca}^{2+}$ channels during repeated pulses, and the data in Figure 7 support this conclusion. Thompson and Coombs (1988) presented data suggesting that $\mathrm{Ca}^{2+}$ channels are clustered in these neurons and Gola et al. (1990) reached the same conclusion from a study of Helix neurons. However, $I_{C}$ facilitation also occurs in patches where there is no measurable $\mathrm{Ca}^{2+}$ current and the value of $F$-index also varies among these patches. This result suggests that factors in addition to $\mathrm{Ca}^{2+}$ channel clustering may contribute to the variability in $F$-index, including local differences in the availability or type of $\mathrm{Ca}^{2+}$ buffers (Neher and Augustine, 1992; Roberts, 1993), clustering of $\mathrm{Ca}^{2+}$ transporters, and restricted $\mathrm{Ca}^{2+}$ diffusion away from the membrane due to physical barriers caused, for example, by membrane infolding.

The shell model used in this study is a simplistic representation of intracellular $\mathrm{Ca}^{2+}$ dynamics. It is only appropriate on a spatial scale large enough for local features, such as the high $\mathrm{Ca}^{2+}$ concentration near open $\mathrm{Ca}^{2+}$ channels, to be spatially averaged, and it is only appropriate after times sufficient for the outer region of cytoplasm to become filled with $\mathrm{Ca}^{2+}$ by diffusion. Both of these conditions were met in this study since changes in $[\mathrm{Ca}]_{i}$ were measured in relatively thick volume elements and the measurements were taken at the end of long, 300 msec, depolarizing pulses. The simulated time course of $[\mathrm{Ca}]_{i}$ accumulation approximates what one sees with fluo-3 imaging but there is an important difference. In the simulations, the increments in $[\mathrm{Ca}]_{i}$ associated with voltage-clamp steps increase in amplitude progressively during repeated pulses. This was not observed in the fluo-3 data. One possible explanation is that the model overestimates $\mathrm{Ca}^{2+}$ influx during later pulses in a stimulus train because it ignores $\mathrm{Ca}^{2+}$ current inactivation. This is not a sufficient explanation, however, because $I_{\mathrm{C}}$ facilitation and $\mathrm{Ca}^{2+}$ accumulation were measured from the soma cap where $\mathrm{Ca}^{2+}$ current inactivation is minimal and because the $\mathrm{Ca}^{2+}$ current achieves a reproducible waveform within about five pulses while simulated $[\mathrm{Ca}]_{i}$ increments continue to increase in amplitude during longer pulse trains. A second factor that may contribute to the difference between the observed and predicted change in $[\mathrm{Ca}]_{i}$ is that the treatment of $\mathrm{Ca}^{2+}$ buffering in the model is inadequate, either because the concentration of $\mathrm{Ca}^{2+}$ buffer sites near the membrane was underestimated or because the model inappropriately assumed that $\mathrm{Ca}^{2+}$ binding sites are fixed in position and unable to diffuse into deeper regions of cytoplasm. A mobile $\mathrm{Ca}^{2+}$ buffer would be expected to reduce $[\mathrm{Ca}]_{i}$ accumulation at the membrane (Neher, 1986; Roberts, 1993).

There is great interest in mechanisms that might give rise to synaptic facilitation, and one theory that is invoked to explain this process is the residual Ca hypothesis (Katz and Miledi, 1968; Zucker, 1989; Sivaramakrishnan et al., 1991; Yamada and Zucker, 1992). According to this idea, $\mathrm{Ca}^{2+}$ ions that enter during action potentials or voltage-clamp pulses accumulate in the cytoplasm of the presynaptic terminal. If the recovery from $\mathrm{Ca}^{2+}$ accumulation is slow, then $\mathrm{Ca}^{2+}$ ions entering during subsequent pulses will add to the residual $\mathrm{Ca}^{2}$ left over from previous pulses. The accumulation of residual $\mathrm{Ca}^{2+}$, combined with the high cooperativity of $\mathrm{Ca}^{2+}$ action at the release mechanism predicts synaptic facilitation. In their $\mathrm{Ca}^{2+}$ accumulation model, Yamada and Zucker (1992) showed that an immobile $\mathrm{Ca}^{2+}$ 
buffer with slow kinetics and located near the membrane can act as an integrator of $\mathrm{Ca}^{2+}$ entry from one action potential to the next. The residual Ca hypothesis for facilitation of transmitter release gives $[\mathrm{Ca}]_{i}$ accumulation a central role and there is experimental support for this idea. For example, Lim et al. (1990) showed that peptide release from terminals of the neurohypophysis increases during the initial pulses in a repetitive series in spite of a progressive decrease in the amplitude of the peak $\mathrm{Ca}^{2+}$ current. They concluded that the facilitation of peptide release results from accumulation of residual $[\mathrm{Ca}]_{i}$. The conclusion from the work reported here is that a similar process of $\mathrm{Ca}^{2+}$ accumulation near the membrane results in $I_{\mathrm{C}}$ facilitation in the cell body. The important difference between $I_{\mathrm{C}}$ facilitation and synaptic facilitation, however, is that the increase in $I_{\mathrm{C}}$ amplitude is linearly related to the increase in $\mathrm{Ca}^{2+}$ accumulation while synaptic transmitter release is a power function of $\mathrm{Ca}^{2+}$ accumulation.

The facilitation of $I_{\mathrm{C}}$ in neuron cell bodies is not expected to have a direct effect on transmitter release at distant terminals. However, $I_{C}$ facilitation in the cell body will affect the duration of somatic action potentials and influence processes such as spike frequency adaptation, poststimulus hyperpolarization, and endogenous pacemaker activity. Because $I_{C}$ facilitates, the character of these molluscan neurons changes in a use-dependent manner, from cells that are dominated by $\mathrm{K}^{+}$currents characterized by fast activation and cumulative inactivation to cells dominated by facilitated $I_{\mathrm{C}}$ with its slower activation, lack of inactivation, and very slow recovery. For these reasons, $I_{\mathrm{C}}$ facilitation is expected to influence the excitability of these neurons during repetitive firing.

\section{References}

Adler EM, Augustine GJ, Duffy SN, Charlton MP (1991) Alien intracellular calcium chelators attenuate neurotransmitter release at the squid giant synapse. J Neurosci 11:1496-1507.

Ahmed Z, Connor JA (1979) Measurement of calcium influx under voltage clamp in molluscan neurons using the metallochromic dye arsenazo III. J Physiol (Lond) 286:61-82.

Ahmed Z, Connor JA (1988) Calcium regulation by and buffer capacity of molluscan neurons during calcium transients. Cell Calcium 9:5769.

Aldrich RW, Getting PA, Thompson SH (1979) Inactivation of delayed outward current in molluscan neurone somata. J Physiol (Lond) 291:507-530.

Allbritton NL, Meyer T, Stryer L (1992) Range of messenger action of calcium ion and inositol 1,4,5-trisphosphate. Science 258:18121815.

Baker PF, Schlaepfer W (1978) Uptake and binding of calcium by axoplasm isolated from giant axons of Loligo and Myxicola. J Physiol (Lond) 276:103-125.

Barish ME, Thompson SH (1983) Calcium buffering and slow recovery kinetics of calcium-dependent outward current in molluscan neurones. J Physiol (Lond) 337:201-220.

Blumenfeld H, Zablow L, Sabatini B (1992) Evaluation of cellular mechanisms for modulation of calcium transients using a mathematical model of fura- $2 \mathrm{Ca}^{2+}$ imaging in Aplysia sensory neurons. Biophys J 63:1146-1164.

Chad JE, Eckert R (1984) Calcium domains associated with individual channels can account for anomalous voltage relations of Ca-dependent responses. Biophys J 45:933-999.

Chagneux H, Ducreux C, Gola M (1989) Voltage dependent opening of single calcium-activate potassium channels in Helix neurons. Brain Res 488:336-340.

DiPolo R, Beauge L (1983) The calcium pump and sodium-calciumexchange in squid axons. Annu Rev Physiol 45:313-324.

Fryer MW, Zucker RS (1993) $\mathrm{Ca}^{2+}$-dependent inactivation of $\mathrm{Ca}^{2+}$ current in Aplysia neurons: kinetic studies using photolabile $\mathrm{Ca}^{2+}$ chelators. J Phvsiol (Lond) 464:501-528.
Gola M, Crest M (1993) Colocalization of active $K_{C_{a}}$ channels and $\mathrm{Ca}^{2+}$ channels within $\mathrm{Ca}^{2+}$ domains in Helix neurons. Neuron 10 689-699.

Gola M, Ducreux C, Chagneux H (1990) $\mathrm{Ca}^{2+}$-activated $\mathrm{K}^{+}$current involvement in neuronal function revealed by in situ single-channel analysis in Helix neurons. J Physiol (Lond) 420:73-109.

Gorman ALF, Thomas MV (1980) Potassium conductance and internal calcium accumulation in a molluscan neuron. J Physiol (Lond) 308:287-313.

Herman A, Hartung K (1982) Properties of a Ca-activated K conductance in Helix neurones investigated by intracellular $\mathrm{Ca}$ iontophoresis. Pfluegers Arch 393:248-253.

Hodgkin AL, Keynes RD (1957) Movements of labelled calcium in squid axons. J Physiol (Lond) 138:253-281.

Ikemoto Y, Ono K, Yoshida A, Akaiki N (1989) Delayed activation of large-conductance $\mathrm{Ca}$-activated $\mathrm{K}$ channels in hippocampal neurons of the rat. Biophys $\mathrm{J} 56: 207-212$.

Johnson BD, Byerly L (1991) Control of neuronal calcium current by intracellular calcium. Biomed Res 12[Suppl 2]:49-52.

Johnson JW, Thompson S (1989) Measurement of non-uniform current density and current kinetics in Aplysia neurons using a large patch method. Biophys J 55:299-308.

Kao JPY, Harootunian AT, Tsien RY (1989) Photochemically generated cytosolic calcium pulses and their detection with fluo-3. J Biol Chem 264:8179-8184.

Katz B, Miledi R (1968) The rolc of calcium in ncuromuscular facilitation. J Physiol (Lond) 195:481-492.

Lando L, Zucker RS (1989) "Caged calcium" in Aplysia pacemaker neurons. Characterization of calcium-activated potassium and nonspecific cation currents. J Gen Physiol (Lond) 93:1017-1060.

Lim NF, Nowycky MC, Bookman RJ (1990) Direct measurement of exocytosis and calcium currents in single vertebrate nerve terminals. Nature 344:449-451.

Lux HD, Hofmeier G (1982) Activation characteristics of the calciumdependent outward potassium current in Helix. Pfluegers Arch 394: $70-77$.

Meiri H, Zelinger J, Rahamimoff R (1986) A possible involvement of the $\mathrm{Na}-\mathrm{Ca}$ exchanger in regulation of transmitter release at the frog neuromuscular junction. In: Calcium, neuronal function and transmitter release (Rahamimoff, Katz B, eds), pp 239-254. Boston: Nijhoff.

Merritt JE, McCarthy SA, Davies MPA, Moores KE (1990) Use of fluo- 3 to measure cytosolic $\mathrm{Ca}^{2+}$ in platelets and neutrophils. Biochem J 269:513-519.

Mulkey RM, Zucker RS (1992) Posttetanic potentiation at the crayfish neuromuscular junction is dependent on both calcium and sodium ion accumulation. J Neurosci 12:4327-4336.

Müller TH, Partridge LD, Swandulla D (1993) Calcium buffering in bursting Helix pacemaker neurons. Pfluegers Arch 425:499-505.

Neher E (1986) Concentration profiles of intracellular calcium in the presence of a diffusible chelator. Exp Brain Res 14:980-992.

Neher E, Augustine GJ (1992) Calcium gradients and buffers in bovine chromaffin cells. J Physiol (Lond) 450:273-301.

Nowycky MC, Pinter MJ (1993) Time courses of calcium and calciumbound buffers following calcium influx in a model ccll. Biophys J 64 : 77-91.

Premack BA, Thompson S, Coombs-Hahn J (1989) Clustered distribution and variability in kinetics of transient $\mathrm{K}$ channels in molluscan neuron cell bodies. J Neurosci 9:4089-4099.

Requena J (1983) Calcium transport and regulation in nerve fibers. Annu Rev Biophys Bioeng 12:237-257.

Roberts WM (1993) Spatial calcium buffering in saccular hair cells. Nature 363:74-76.

Roberts WM, Jacobs RA, Hudspeth AJ (1990) Colocalization of ion channels involved in frequency selectivity and synaptic transmission at presynaptic active zones of hair cells. J Neurosci 10:3664-3684.

Sala F, Hernandez-Cruz A (1990) Calcium diffusion modeling in a spherical neuron. Relevance of buffering properties. Biophys J 57: 313-324.

Sivaramakrishnan S, Brodwick MC, Bittner GD (1991) Presynaptic facilitation at the crayfish neuromuscular junction: role of calciumactivated potassium conductance. J Gen Physiol 98:1181-1196.

Smith SJ, Thompson SH (1987) Slow membrane currents in bursting pacemaker neurones of Tritonia. J Physiol (Lond) 382:425-448.

Smith SJ, Zucker RS (1980) Aequorin response facilitation and intracellular calcium accumulation in molluscan neurons. J Physiol (Lond) 300:167-196. 
Thompson SH (1977) Three pharmacologically distinct potassium channels in molluscan neurons. J Physiol (Lond) 265:465-488.

Thompson S, Coombs J (1988) Spatial distribution of Ca currents in molluscan neuron cell bodies and regional differences in the strength of inactivation. J Neurosci 8:1929-1939.

Thompson S, Smith SJ, Johnson J (1986) Slow outward tail currents in molluscan bursting pacemaker neurons, two components differing in temperature sensitivity. J Neurosci 6:3169-3176.
Wang SS-H, Thompson S (1992) A-type potassium channel clusters revealed using a new statistical analysis of loose-patch data. Biophys J 63:1018-1025.

Yamada WM, Zucker RS (1992) Time course of transmitter release calculated from simulations of a calcium diffusion model. Biophys $\mathrm{J}$ 61:671-782.

Zucker RS (1989) Short-term synaptic plasticity. Annu Rev Neurosci 12:13-31. 